


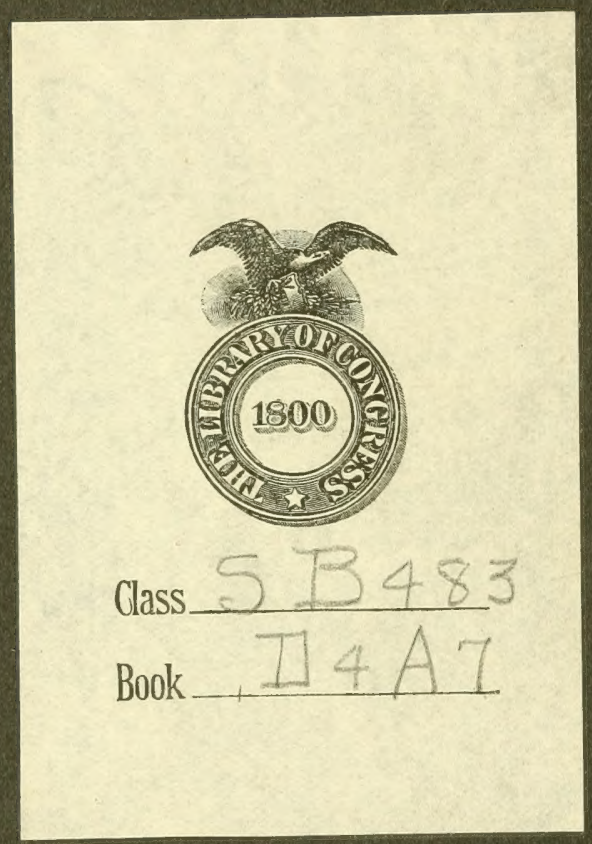




\title{
BULLETIN
}

\section{DETROIT, ITS PARKS AND RECREATIONAL SYSTEMS}

\section{ANNUAL CONVENTION PROGRAM DETROIT, MICHIGAN A U G U T T 23, 24, 25, 1921}

\author{
ISSUED BY
}

PARKS \& RECREATION MINOT, NORTH DAKOTA 


\title{
THE OFFICIAL JOURNAL
}

\author{
OF THE
}

\section{American Association of Park Superintendents}

should be read by everyone interested in park and recreation work, civic improvement, art, and the natural sciences.

\section{PARKS \& RECREATION}

has departments devoted to Recreation, Landscape and Art, Engineering and Construction, Zoology, Horticulture, Arboriculture, and topics of a pertinent nature.

This magazine is devoted to the dissemination of knowledge, theoretical and practical, relating to the improvement and maintenance of parks and recreation facilities.

Published at Minot, N. Dak.

WILL 0. DOOLITTLE, Minot, Managing Editor A. A. FISK, Chicago, Ill.,

L. P. JENSEN, St. Louis, Mo., EMMETT P. GRIFFIN, East St. Louis, Ill.

Associate Editors.

Subscription and advertising applications should be sent to the publication office at Minot, North Dakota. 


$$
S B 483
$$

$I_{4} A 7$ 



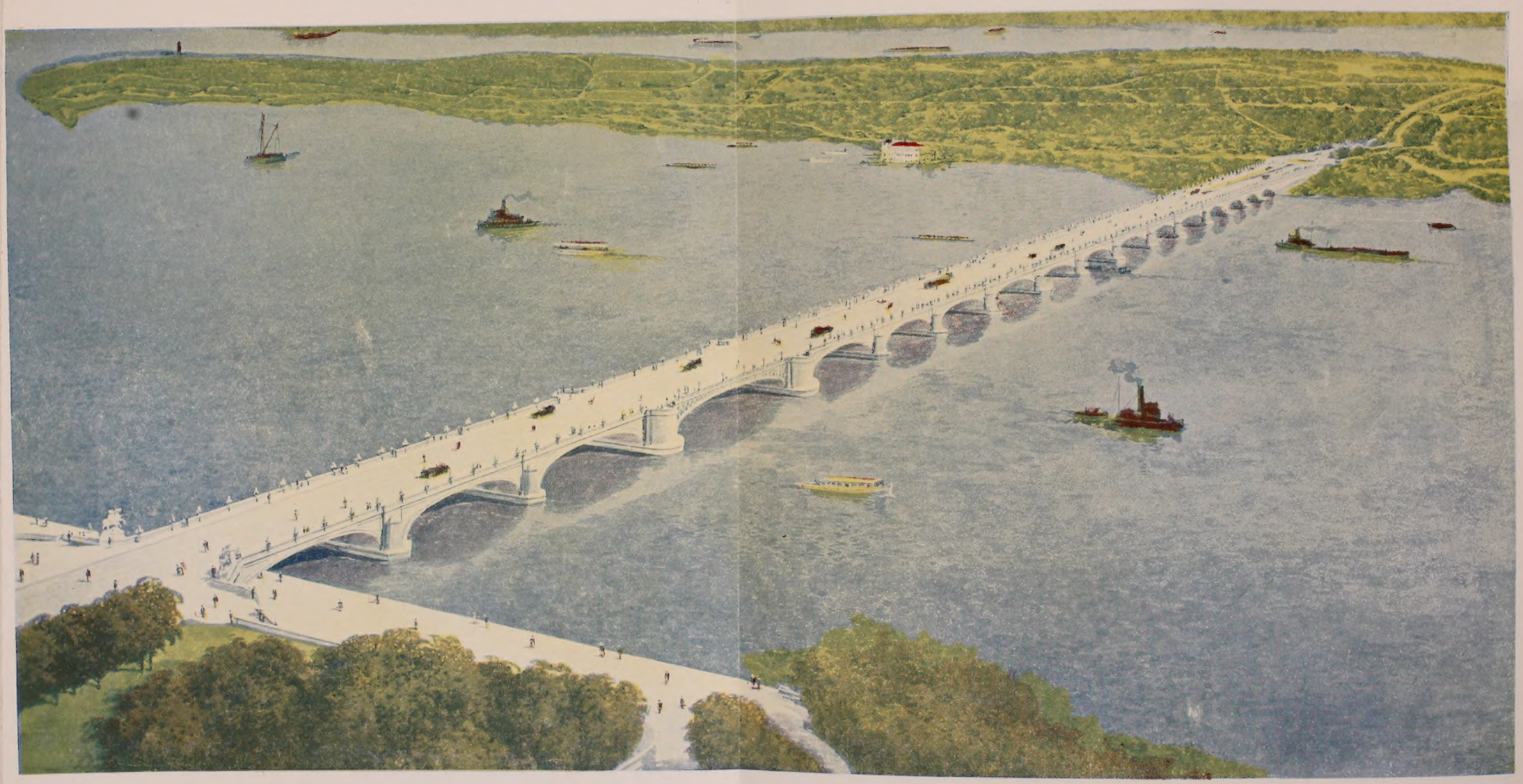




\section{PROGRAM}

\section{Twenty-second Annual Convention \\ American Association of Park Superintendents \\ DETROIT, MICH.}

August 23, 24, 25, 1921

Sunday, August 21

9:00 A. M. Preliminary meeting of Reorganization Committee, Hotel Tuller.

Monday, August 22

10:00 A. M. Meetings of Executive Committee and Reorganization Committee.

10:00 A. M Business Session.

Tuesday, August 23

Addresses of Welcome by Major James Couzens and Park Commissioner Edw. G. Heckel.

Response by Vice President J. V. Burgevin, New York City.

12:00 M. Adjournment.

2:00 P. M. Business Session.

"Essentials of Organization", A. A. Fisk, Chicago, Ill.

Discussion.

New Business.

8:00 P. M. Public Session.

"Conservation of Wild Life", Richard E. Follett, Secretary Detroit Zoological Society.

"Care of Street Trees", C. E. Smith, Superintendent of Forestry and Landscape, Detroit.

"Playgrounds", C. E. Brewer, Commissioner of Recreation, Detroit.

\section{Wednesday, August 24}

9:00 A. M. Public Session.

"Value of Parks to Posterity", L. P. Jensen, Arboriculturist, Missouri Botanical Gardens, St. Louis.

"Parks as Memorials", O. W. Douglas, Chicago, Illinois.

"Woods as Parks", Dr. Filibert Roth, Department of Forestry, University of Michigan.

2:00 P. M. Auto Ride and Visits to City Parks.

5:00 P. M. Picnic Lunch at Palmer Park.

8:00 P. M. Business Session at Hotel.

"A National Botanic Garden", F. L. Mulford, U. S. Department of Agriculture, Washington, D. C.

Thursday, August 25

9:30 A. M. Take ferries at foot of Woodward Avenue for Belle Isle Park. Autos will be waiting at park for a ride and complete inspection of the Belle Isle bathhouse, conservatory and greenhouses, work shops, zoo and aquarium.

1:00 P. M. Dinner at the Belle Isle Casino.

2:30 P. M. "City Planning in Relation to Parks and Boulevards", T. Glenn Phillips, Secretary and Consultant, City Plan Commission, Detroit.

4:00 P. M. Pageant, under auspices of the Recreation Commission

\section{GENERAL INFORMATION}

The Hotel Tuller, located on Grand Circus Park, has been selected as Convention Headquarters. The Tuller is centrally located, and is an excellent hotel. The rates are $\$ 2.50$ a day single and $\$ 4.50$ a day double, all rooms with bath. Other hotels in the vicinity are the Cadillac, rates $\$ 2.00$ up; Statler, $\$ 3.00$ up; and Wolverine, $\$ 2.50$ up.
President Busch will be pleased to make the necessary reservations for those who prefer to have him do so. He suggests that visitors coming into the city take the street cars to be found outside the depot and which go directly to Grand Circus Park, where it is only a step to the hotel. This will be much cheaper than taking the taxies. 


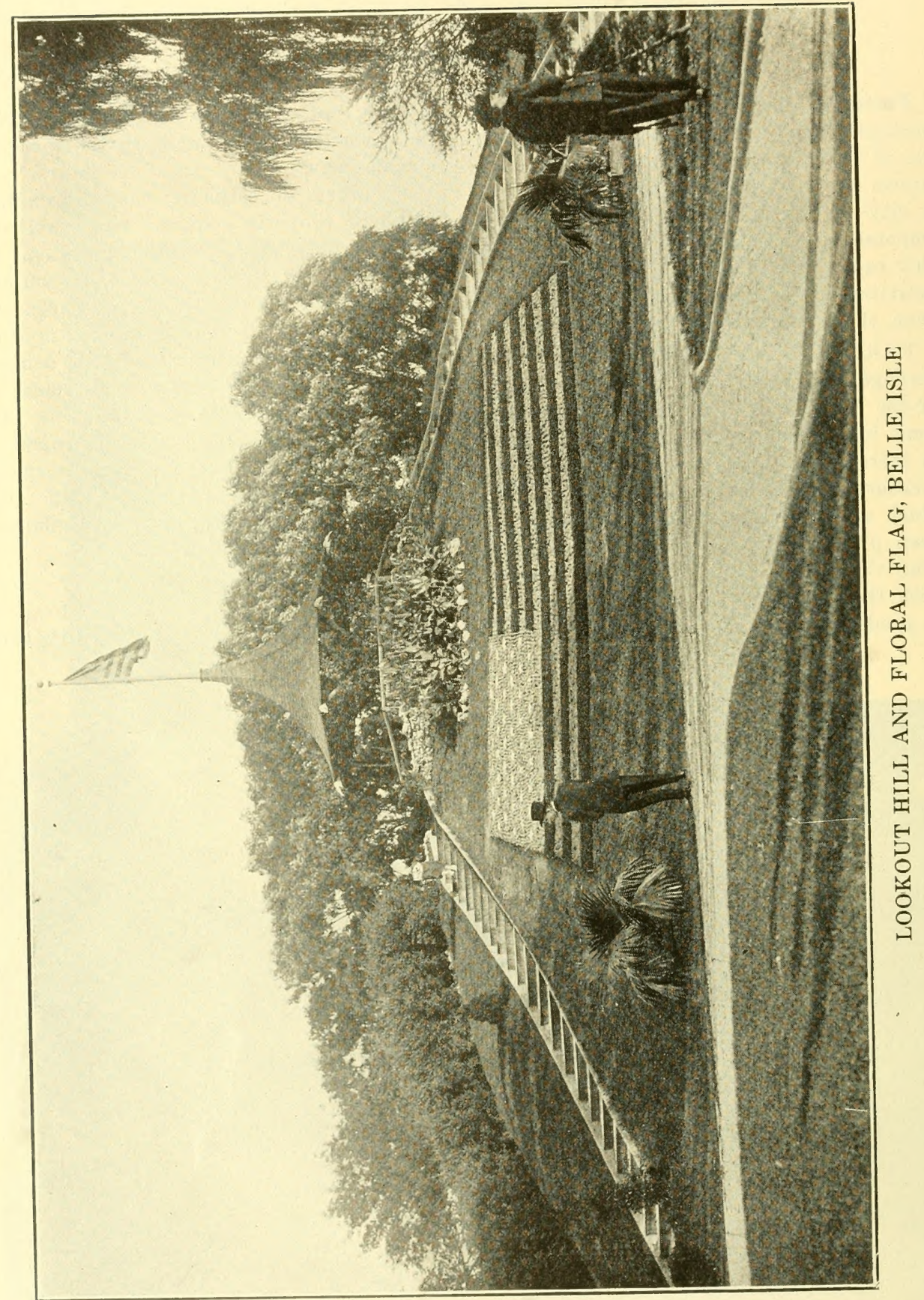




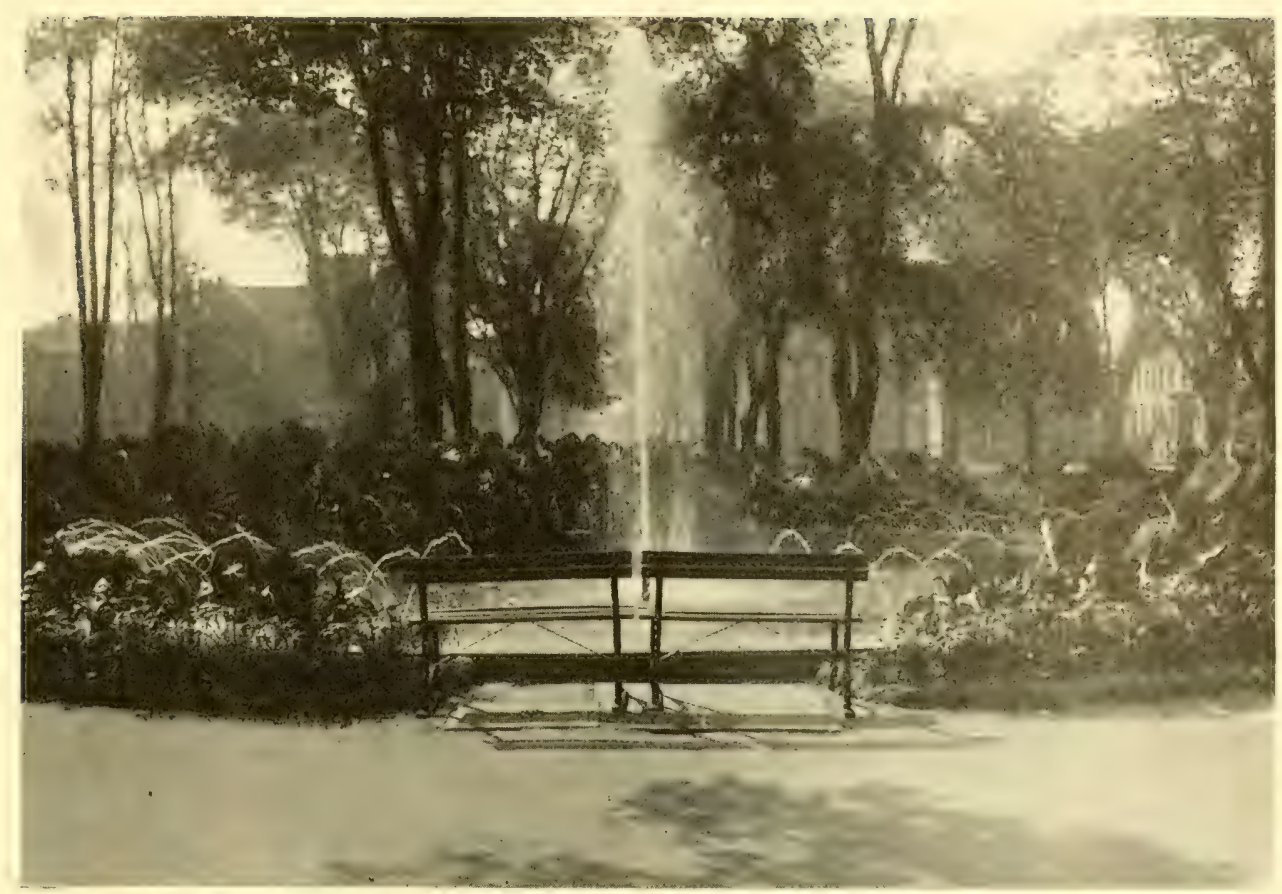

TYPE OF GEYSER FOUNTAIN INSTALLED IN SEVERAL DETROIT PARKS

In addition to these sites the Common Council has approved, and ordered condemned the following:

6 - Park Sites _
3 - Playfields
14 - Playgrounds

The completed recreation system includes about 120 additional playground areas of approximately one acre each, exclusive of the many school-ground improvements and facilities that are being rapidly developed by the Board of Education. The completed system will provide for all phases of recreation activities within the easy reach of every home, so that tiresome journeys or the expense of transportation will not deter people from actively participating in these recreational enjoyments.

In addition to the development of new sites for parks, playgrounds and playfields, the City Plan Commission is preparing official landscape plans for the re-design and planting of all city properties now used for such purposes, in order that ultimately the maximum utility, orderliness and beauty of these public areas may be realized.
We shall not attempt at this time to make any extensive description of the parks of Detroit, other than that depicted by the illustrations. However, a few words concerning the well known Belle Isle are not inappropriate.

\section{Belle Isle}

Prior to 1845 Belle Isle was known as Hog Island. July 4, that year, a party was formally organized to go to the island and rechristen the resort, which had become very popular with Detroiters. The consent of the owner, Barnabas Campau, was not asked. The expedition landed at the foot of the island and after a few minor preliminaries, Mr. E. Goodell made a motion to change the name to Belle Isle. Morgan Bates poured a pitcher of water on the ground and the christening was completed. In 1879 the city bought the island for $\$ 200,000$, and the name was officially changed in 1881. Belle Isle Park is 2 miles long; has $5 \frac{1}{2}$ miles shore drive; has $14 \frac{1}{2}$ miles of driveway; has $51 / 10$ miles gravel walks and contains 704 acres.

Personnel of Departments

Col. Edw. G. Heckel is commissioner of 


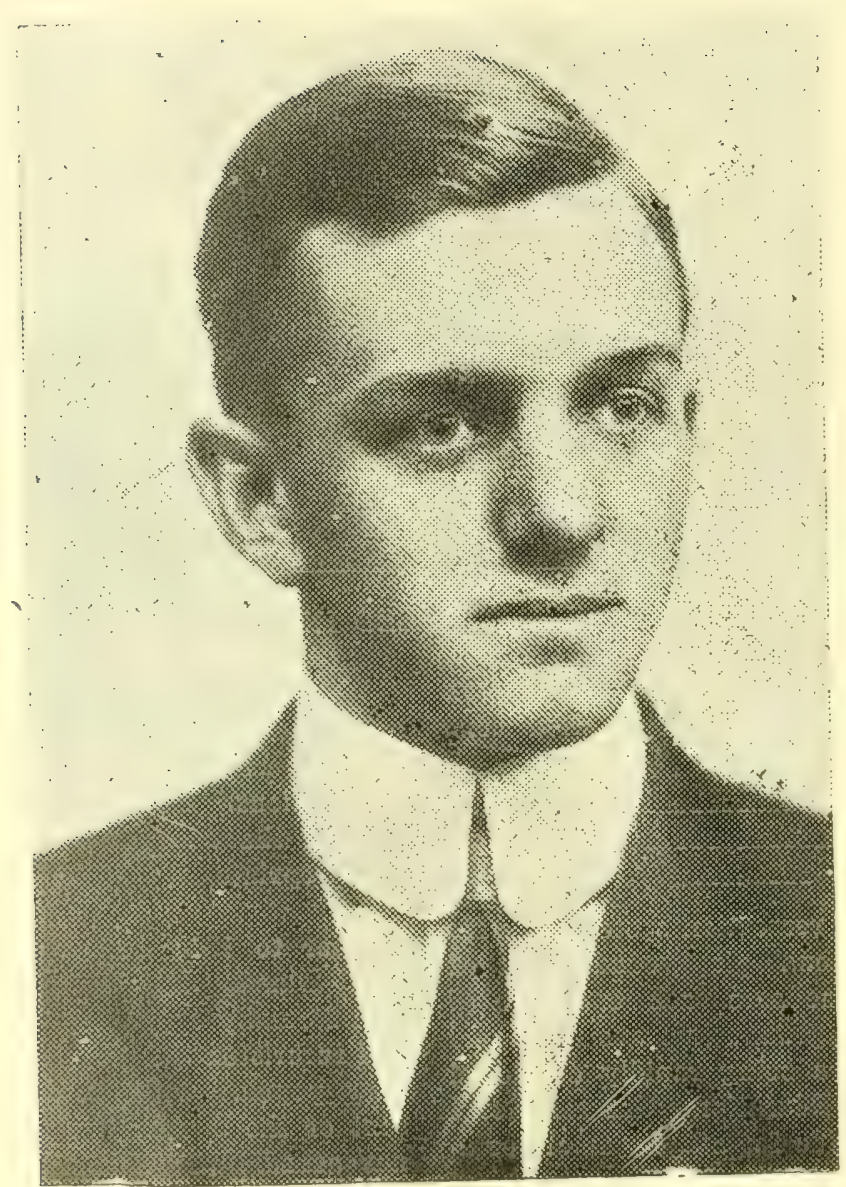

C. E. BREWER, COMMISSIONER OF RECREATION, DETROIT, MICH. 


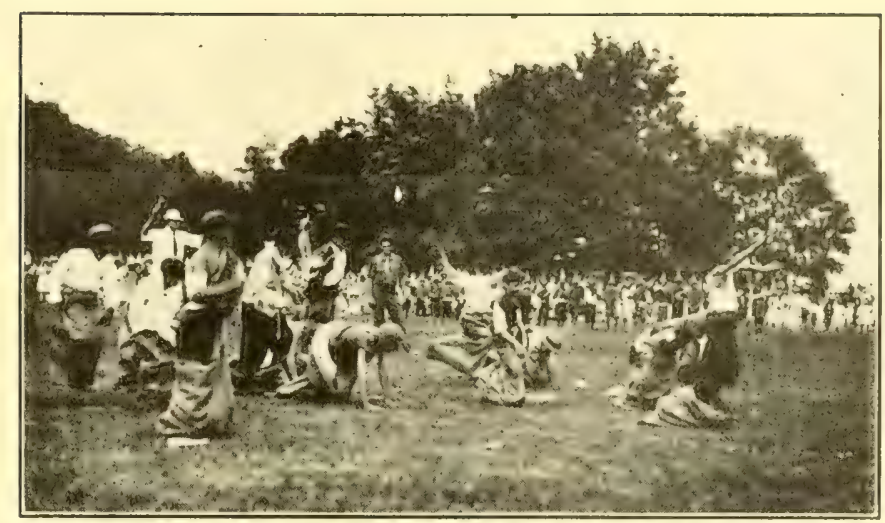

GAMES ON FIELD DAY

the Department of Parks and Boulevards and Capt. H. W. Busch is secretary and general superintendent. C. E. Brewer is commissioner of the Department of Recreation and T. Glenn Phillips is secretary and consultant for the City Plan Commission. There is a fine spirit of cooperation among these departments. Many of the recreation fields are located in the public parks, the Department of Parks and Boulevards doing the construction and maintenance work and the Department of Recreation supervising the play.

\section{Department of Recreation}

In the July issue of PARKS \& RECREATION, C. E. Brewer, commissioner of recreation, gave an extended account of the work of the Department of Recreation in the city of Detroit. It is not necessary to repeat this article in this bulletin; but the popularity of the work is well shown by the following table of attendance:

Attendance July 1, 1920 - June 30, 1921

\begin{tabular}{|c|c|c|c|c|c|}
\hline & Boys & Girls & Men & Women & Monthly \\
\hline July, 1920 & 236,352 & 191,130 & 198,825 & 79,148 & 705,455 \\
\hline August & 141,525 & 126,210 & 175,741 & 57,913 & 504,389 \\
\hline September & 100,618 & 54,210 & 131,445 & 35,689 & 321,962 \\
\hline October & 96,704 & 61,627 & 89,035 & 28,489 & 275,853 \\
\hline November & 79,257 & 41,711 & 53,230 & 19,766 & 193,964 \\
\hline December _. & 63,004 & 45,526 & 32,916 & 21,849 & 163,295 \\
\hline January, 1921 & 73,239 & 68,704 & 42,198 & 42,152 & 226,383 \\
\hline February _. & 64,865 & 43,250 & 45,124 & 19,063 & 172,302 \\
\hline March & 60,960 & 44,382 & 56,321 & 24,111 & 185,777 \\
\hline April _..- & 91,584 & 56,708 & 98,380 & 32,207 & 278,879 \\
\hline May $\ldots \ldots \ldots$ & 161,367 & 101,125 & 233,794 & 76,957 & 573,243 \\
\hline \multirow[t]{2}{*}{ June } & 214,671 & 165,683 & 358,146 & 113,711 & 852,211 \\
\hline & $1,384,146$ & $1,000,356$ & $1,518,156$ & 551,055 & $4,453,713$ \\
\hline
\end{tabular}

Total Attendance by Sex

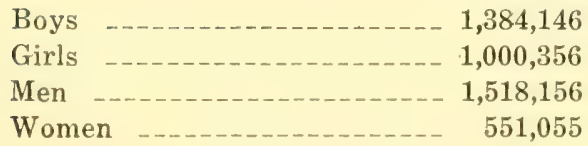

Male _..._._. 2,902,302

Female _... 1,551,411 


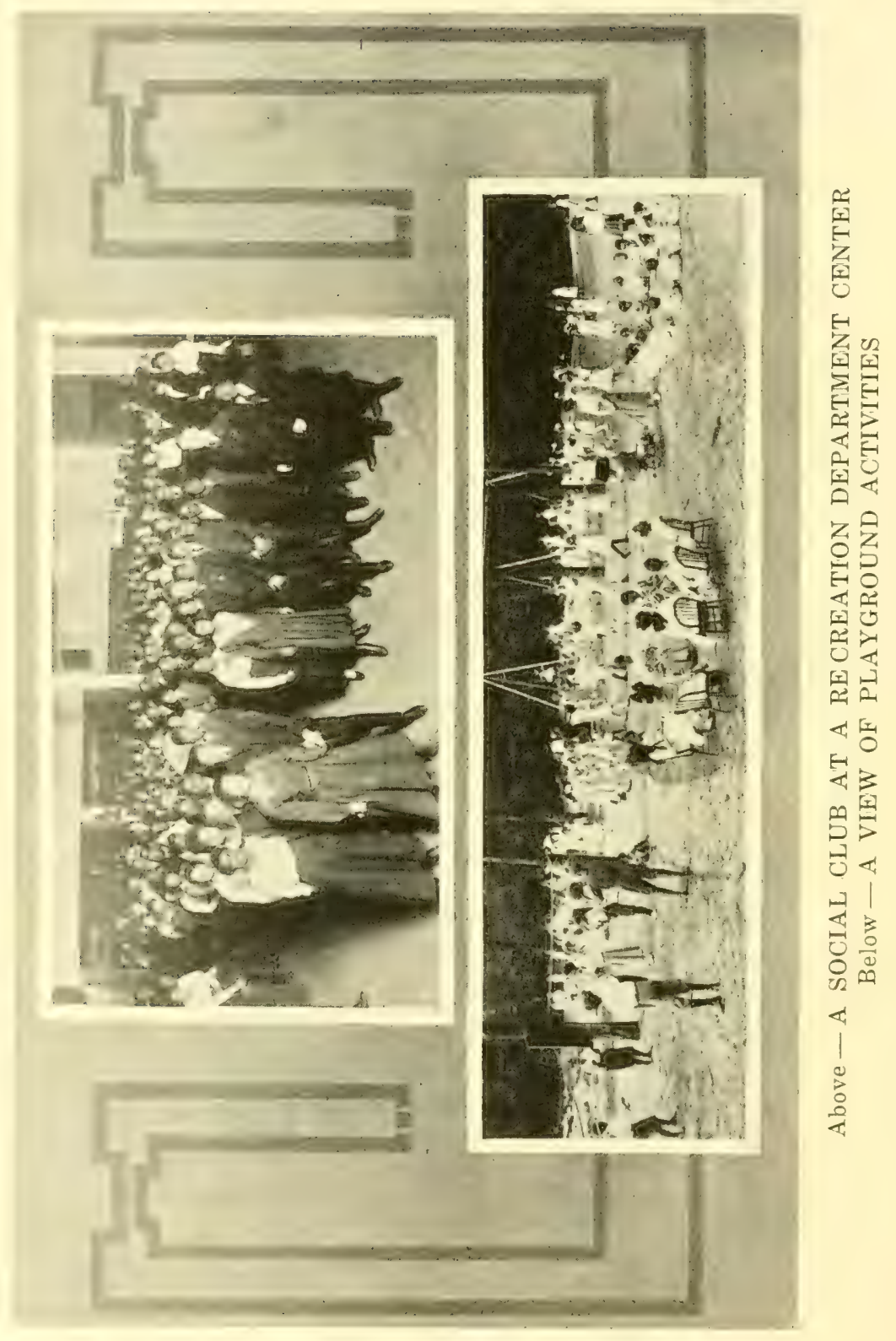


Comparison of Attendance of Adults and Children

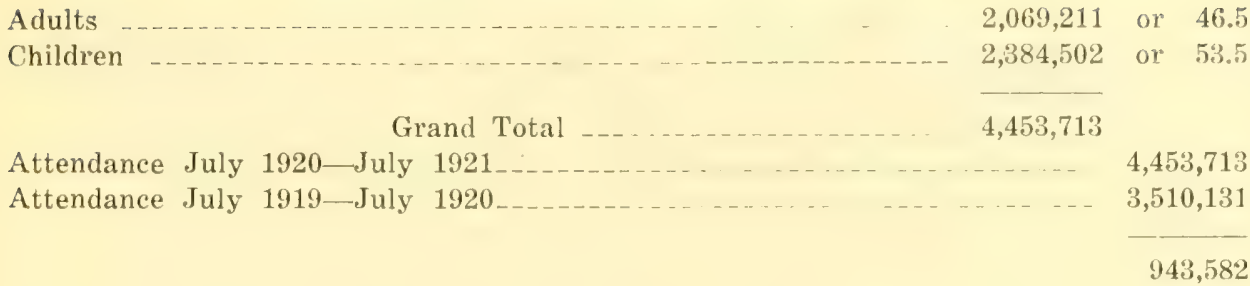

A mention of the second annual water carnival, which was held on the Canadian side of Belle Isle on August 6, may be of interest to the readers of this bulletin. This is one of Detroit's great play events, and consists of swimming races, canoe and rowing races, sail yacht races, power boat races, canoe pageant and band concerts. It was held under the ausnices of the Depart- ment of Parks and Boulevards and the Department of Recreatior, assisted by clubs and individuals interested in water sports, and over three hundred prizes were awarded. Probably in no other city in the United States is there better opportunity for the holding of these water carnivals than on the magnificent water-front of Detroit.

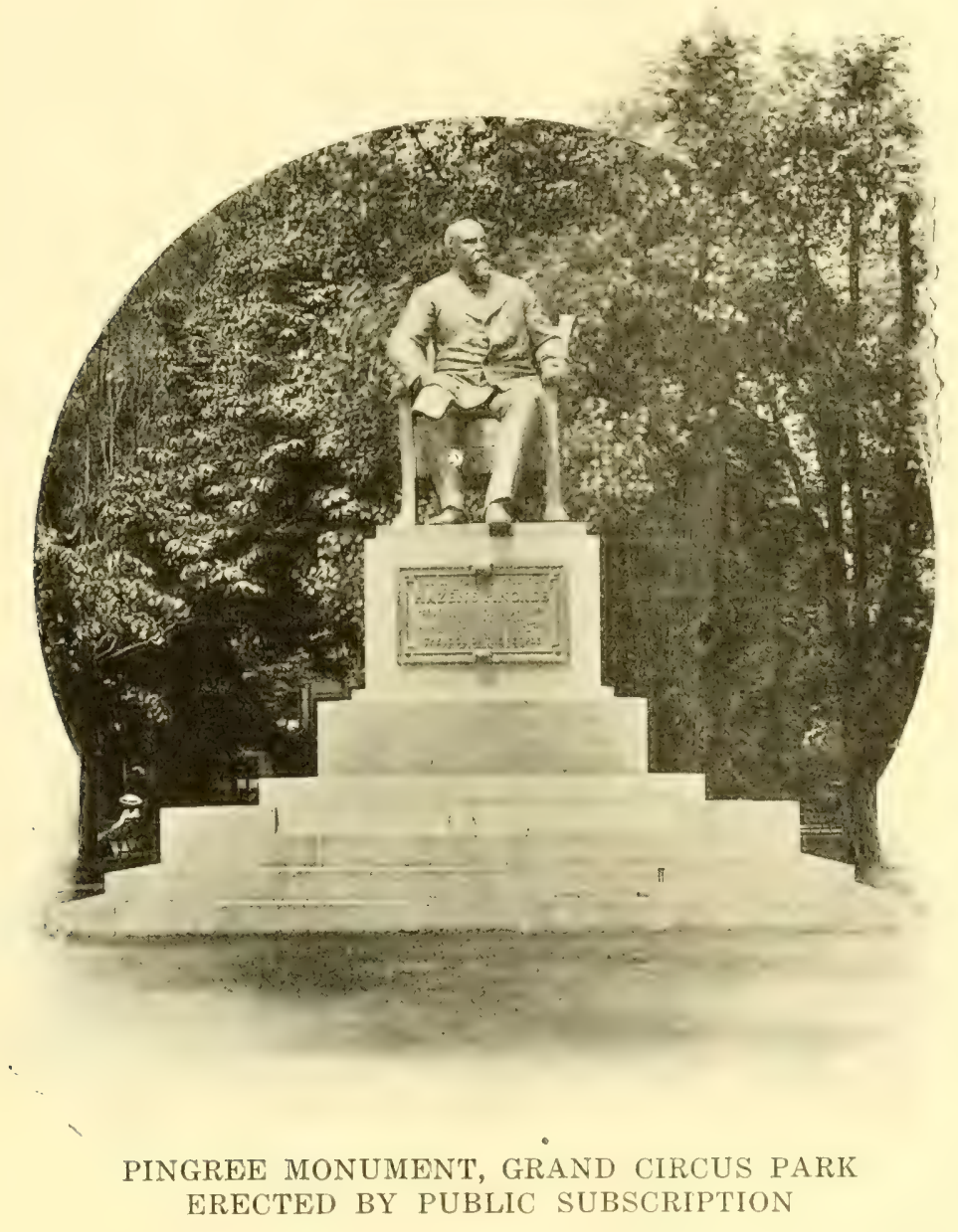




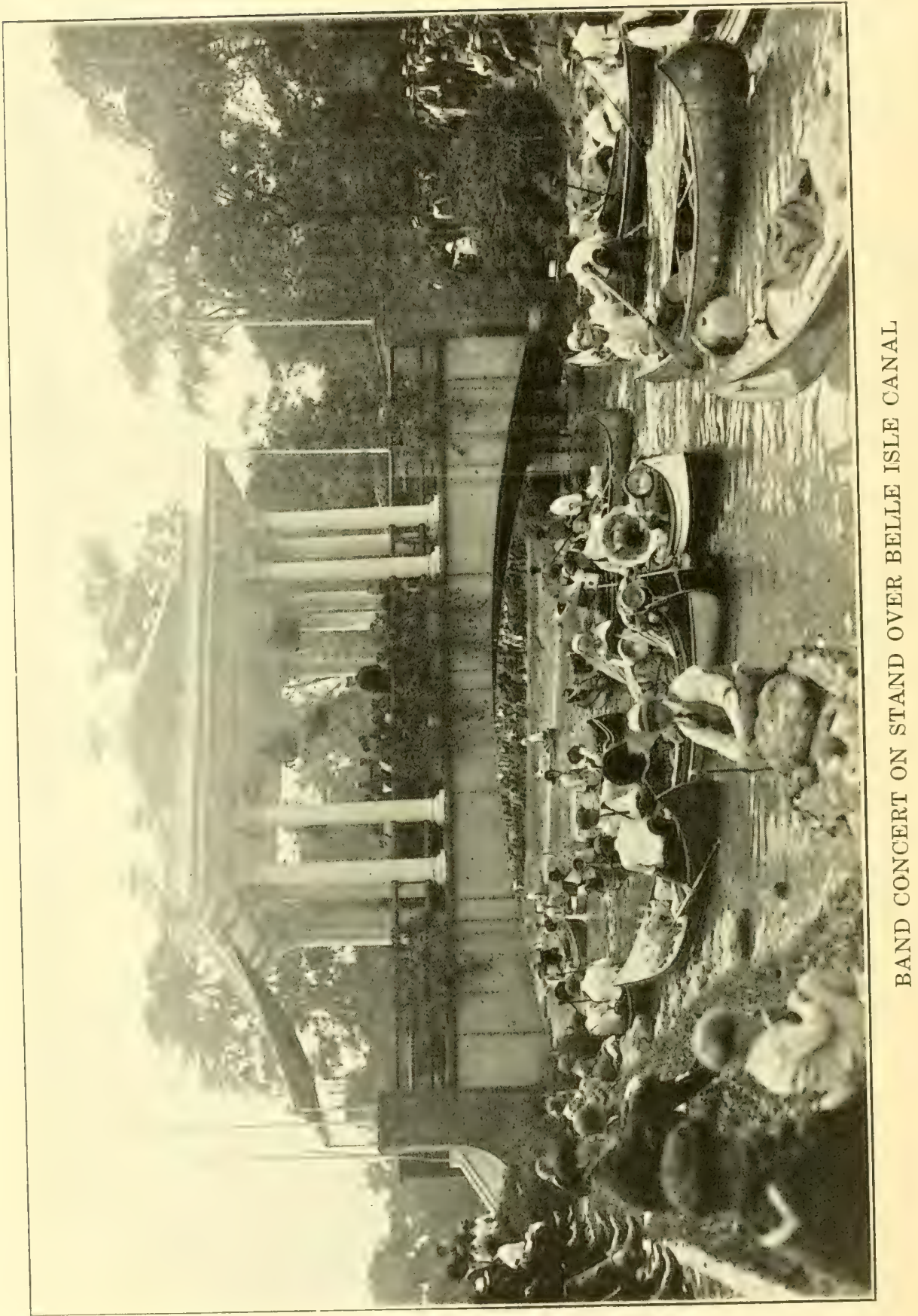




\title{
SPLENDID WORK OF AR'T
}

\author{
Proposed Belle Isle Bridge Product of Careful \\ Study, Artistic Design and Engineering Skill.
}

The earliest suggestion, of record, for a bridge to connect Detroit with Belle Isle, was made in February, 1885. At this time the island was almost entirely undeveloped and was used largely as a picnic ground, visitors being transported to the island by boat.

In December, 1885, a resolution, for building a bridge to the island, was adopted by the city council, and a site for the proposed bridge was purchased soon afterward. Plans and specifications for this bridge were approved in February, 1886; the contract for construction was awarded in September, 1887 , for $\$ 295,000$ and the bridge was completed and accepted on June 25, 1889.

It was located at the end of East. Grand Boulevard and was a steel truss bridge, with plank floor and timber stringers. There were twelve 156-foot through spans, one 318-foot swing span, and five 88-foot pony truss spans, making a total length between abutments of 2,628 feet. The width of the roadway was 26 feet, and that of the sidewalks 9 feet, making the total width of the bridge 44 feet. The height above ordinary water level was about 19 feet 9 inches to the bottom of the vertical posts, or clearance line, and 22 feet to the top of the bridge floor.

With the increase in population of the City of Detroit and the development of Belle Isle the structure became inadequate to the demands made upon it. The design, moreover, was out of keeping with the further development of Belle Isle.

These facts resulted in agitation for replacing the old bridge with one adequate for the traffic needs and architecturally suitable as a connecting link between the City of Detroit and its finest park. As a result, a small appropriation was made in May, 1914, for the purpose of making a preliminary study for a new bridge.

In April, 1915, the timber floor of the then existing bridge was destroyed by fire, resulting in the collapse of the major portion of the steel superstructure. This was followed by an appropriation, made in May, 1915, for the construction of a temporary bridge to the island, and during the following month a special election was ordered for the purpose of authorizing a $\$ 2,000,000$ bond issue to construct a new bridge. At this election which was held July 9, 1915 , the proposition failed to carry.

The present temporary bridge was completed in August, 1916, under the appropriation of May, 1915, This structure is located about 175 feet down-stream from and practically parallel to the old bridge. It is a pile trestle with I-beam stringers and plank floor. A swing span is located about 500 feet from the Detroit end.

The over-all width is 36 feet, including two sidewalks each 7 feet and a roadway 22 feet in width. The floor at the Detroit side is 25 feet above mean water and slopes down to the swing span at a two per cent grade. On the Belle Isle side of the swing span the grade is one per cent for about 500 feet and level for the remainder of the distance to the island.

\section{The Proposed Bridge}

The present design for the proposed Belle Isle Bridge has been developed by comprehensive study of the condjtions fundamentally affecting it. The conclusions relative to site, general dimensions, appropriateness of structural type and design are based therefore upon practical requirements, with due regard to the aesthetic features of the proposed structure which will be a connecting link in the municipal system of parks and boulevards.

The value of the region between East Grand Boulevard and the water works for manufacturing and shipping is limited by the depth and width of the river channel, there being insufficient space for turning large boats, and by the lack of railroad facilities. This region contains one of Detroit's finest groups of residences whose well-kept gardens greatly enhance the interest of the river shore and are among the most beautiful features of the city.

The river basin between the island and the mainland above the site of the bridge ranks with the best for boating to be found in American cities. It is the only portion 


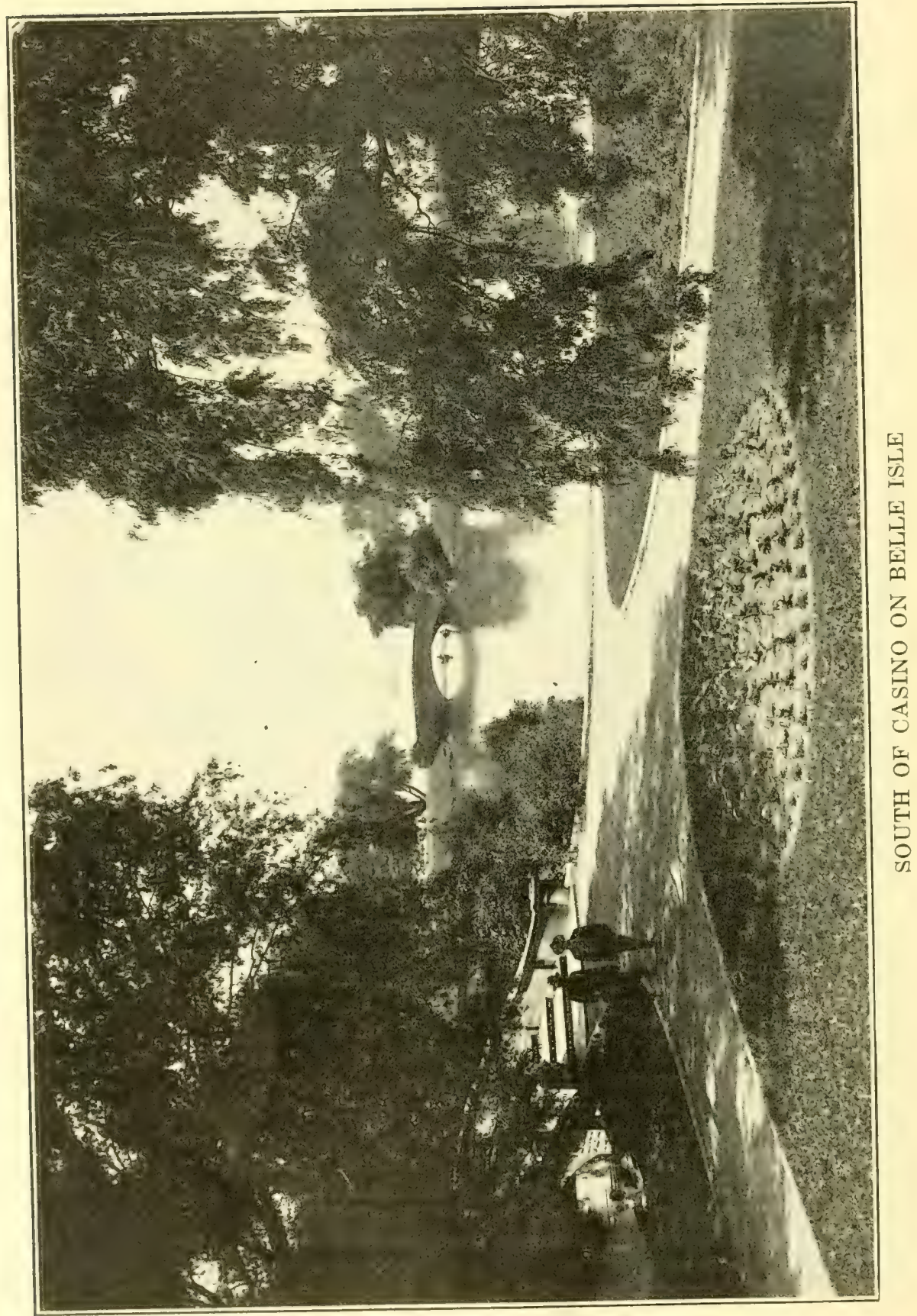


of the river near the city where small boats can move with freedom and safety, and is one of Detroit's greatest assets. Few foreign cities have a more attractive water front and its beauty and availability depend upon the retention and development of the present character of its shores.

The proposed bridge has an unusually favorable setting. The site at the end of East Grand Boulevard is a conspicuous one, making a bridge at this point visible from all boats and from the Detroit and island shores, as well as from part of the Canadian shore. The city's property known as the Detroit approach is 200 feet wide and is 800 feet in length from Jefferson Avenue to the harbor line. The center line or axis of this property does not coincide with that of the boulevard which is 150 feet wide. The river channel, used primarily by tugs, scows and yachts, is near the Detroit shore which is considerably higher than the level of the island. At the island end of the old bridge is an open space beyond which are canals, bridges, roads and fine high trees.

The direction of river current as indicated by government records makes an angle of about 86 degrees with the axis of the old bridge. Using the old location as that for the new structure, it would probably be necessary to use skewed spans in order to keep within the displacement considered allowable for the bridge piers. In that case the piers would not be normal to the bridge axis and if a bascule span were required the satisfactory design of the bascule piers would be practically impossible. A survey of the direction of river current made by the Consulting Board verifies the above angle in the channel near the mainland end of the bridge but shows angles of more nearly 90 degrees near the island end. The most desirable arrangement of the piers would be to make them normal to the axis of the bridge, and this can be done provided the island end is moved somewhat up-stream. Since, moreover, additional space is needed at the island approach and will be provided by such a change in the bridge axis without destroying any of the trees, the island end of the proposed bridge is placed 150 feet further up-stream than that of the old one and the approach is extended to the harbor line.

\section{General Description}

The allowable obstruction to flow of water and interference with shipping is under complete control of the War Department, through its engineers. The piers must not in number and size seriously prevent the flow of water and ice, and the interests of navigation must be considered in determining clearances above the water line. After careful study of the situation during which the government engineer in charge of this district and the largest shipping interests were consulted, it has been tentatively assumed that a bridge twenty-two hundred feet long and consisting of nineteen fixed spans varying from 74 to 135 feet each, with a maximum clearance of 30 feet above mean water-line in three channel spans, would provide sufficient water-way and equitable service for the traffic over and under the bridge. The width of the bridge is to be $83^{\prime}$ having a roadway of $59^{\prime}$ including space for street car tracks, should these be used, and two sidewalks each twelve feet wide.

\section{Structural Type}

Data obtained from surveys, borings and pile loading tests at the site of the proposed bridge indicate that a structure designed upon cantilever principles would best fit the natural conditions. Other structural types were carefully considered but the great distance to rock and the plastic condition of the overlying soil was the most important eliminating factor. Moreover the curved arms of the cantilever construction give pleasing lines consistent with the character of the bridge as a civic and park structure. The water level is subject to slight changes, hence the curved arms can spring from the piers at a low point and an open spandrel treatment is practicable, giving an effect of lightness without sacrificing that of strength and dignity. The advantages with respect to appearance as well as permanence were deciding factors in the selection of reinforced concrete as the most suitable material.

\section{Selection of Type}

A comprehensive study of the whole foundation problem in the light of information as described, led to the following conclusions relative to the type best adapted for the proposed structure.

1. That it should be as light as possible.

2. That the foundation reactions should be entirely vertical. 


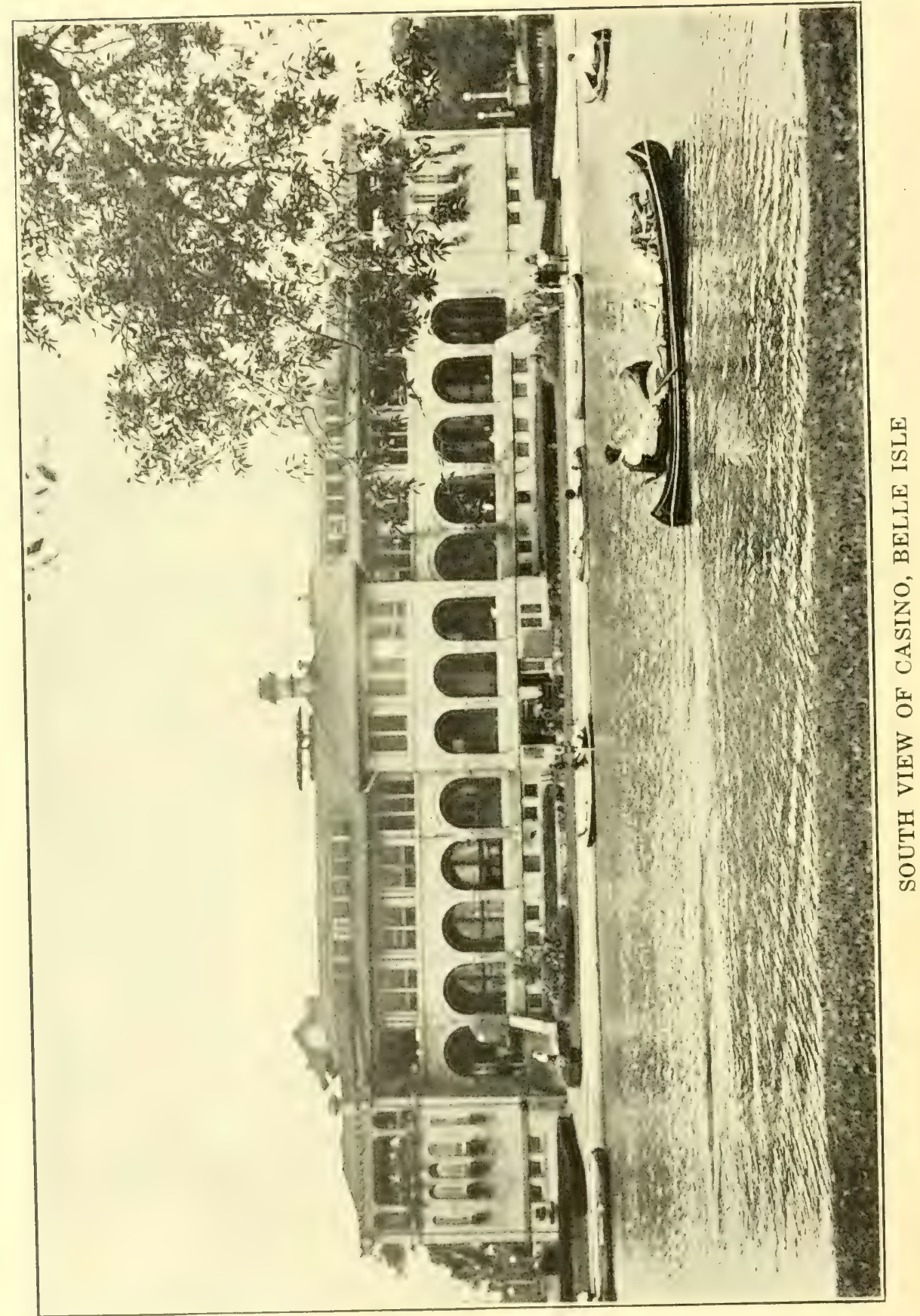




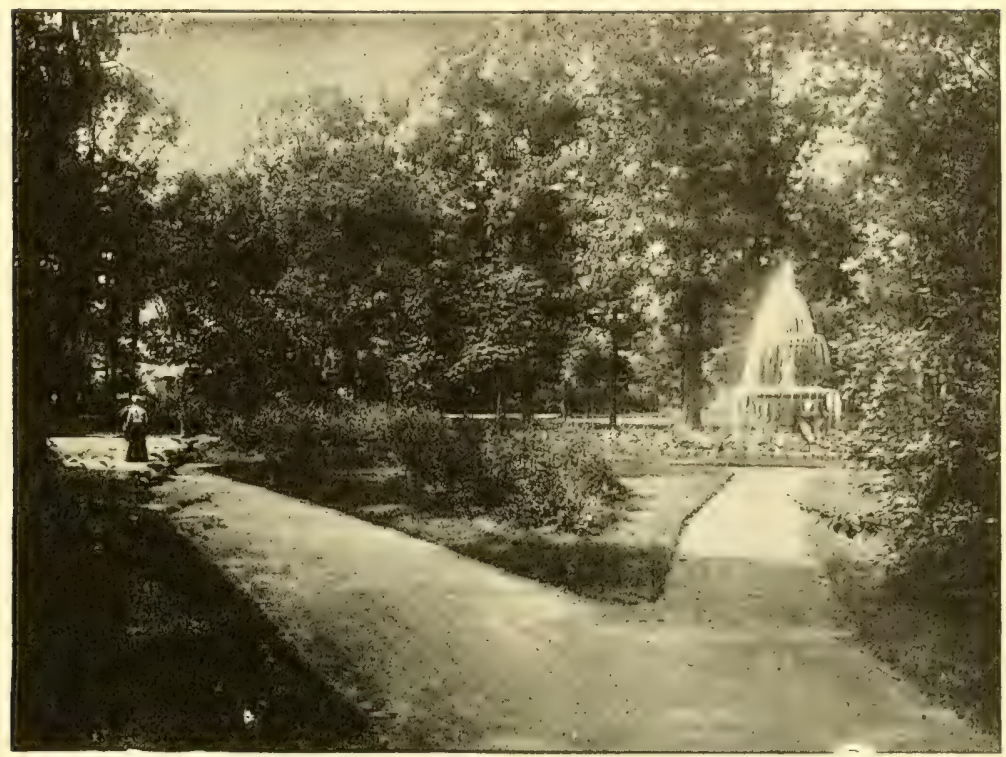

DISPLAY FOUNTAIN IN CLARK PARK, DETROIT

The problem was thus narrowed down to consideration of the relative merits as to cust and appearance of a comparatively few types.

Arches and cantilevers are types which economically follow pleasing lines, and therefore investigation of their relative adaptability was made by means of sketches and estimates of costs. Two-hinged, threehinged and hingeless arches were considered, and while each has its advantages, all are dependent for stability upon lateral resistance of the soil. Furthermore, an intelligent analysis of stresses must be based upon assumed and uncertain displacements of the piers. For these reasons and in view of the soil conditions as described above, a structure based upon the cantilever principle with vertical reactions is considered preferable. Accordingly, the design contemplates the construction of a series of spans consisting of curved cantilever arms extending in both directions from each of the piers to which they are rigidly connected. The arms are joined near the centers of the spans by simply supported units. The advantage of the latter arrangement instead of using a shear joint connecting the cantilever arms, as is sometimes done in structures of this sort, is to avoid damage which might result from unequal settlement of the piers. The cantilever arms are constructed of concrete reinforced with structural steel, the latter being so designed that it may be completely fabricated in the shops, erected in advance of the concrete work and used to carry the forms for the concrete.

February 25, 1919

Resolution by Common Council for an amendment to the Revised Charter of the City of Detroit whereby there is added-a chapter, entitled Chapter I of Title XI, conferring upon the Common Council of the City of Detroit power to erect a bridge over the American channel of the Detroit River between Belle Isle and the mainland at the intersection of Jefferson Avenue \& East Grand Boulevard; to provide an approach or approaches thereto; to expend therefore a sum not to exceed three million dollars.

April 7, 1919

Resolution of Feb. 25, 1919, submitted to the electors of this city April 7, 1919, and carried by a majority of over $60 \%$.

April 29, 1919.

Joint report to Common Council from Commissioner of Public Works, the Commissioner of Parks and Boulevards, and the City Plan Commission, recommending that the proposed bridge to Belle Isle be built without a draw and that the type of bridge 


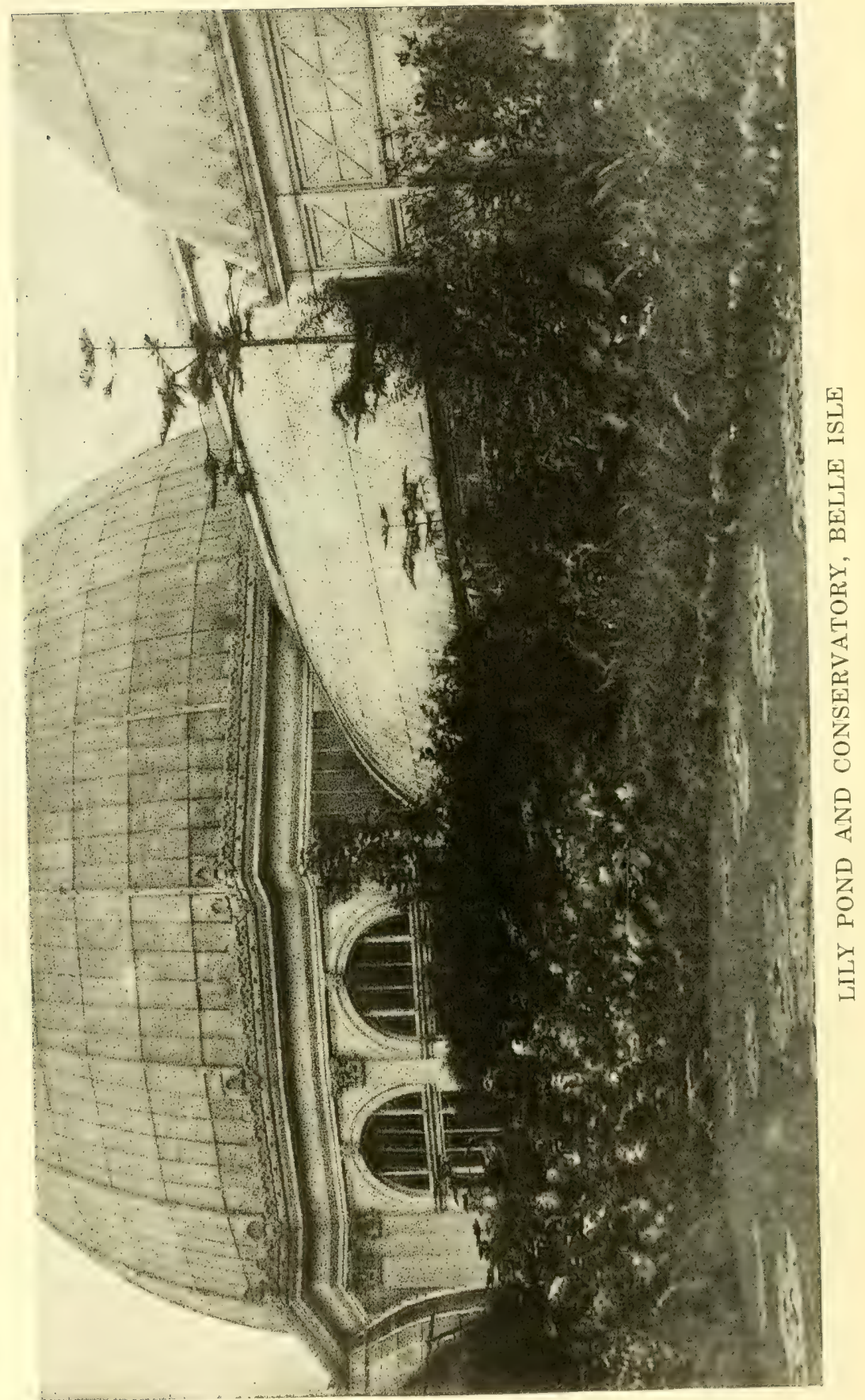


as shown in the preliminary plans proposed by the Belle Isle Bridge Consulting Board be adopted, and that the consulting services of the Board be retained.

May $6,1919$.

Above report approved by Common Council and Commissioner of Public Works authorized and directed to secure the necessary permission and authority from the Board of Supervisors of Wayne County and the War Department to construct a bridge to Belle Isle without a draw or lift span.

May 21, 1919.

A petition was filed by the City of Detroit with the Board of Supervisors of the County of Wayne for consent, permission and authority for the City of Detroit to build, construct and maintain a permanent bridge without a draw or lift span across the Detroit River from East Grand Boulevard to Belle Isle.

June 23, 1919.

At a special meeting of the Board of Supervisors of Wayne County the above petition was granted.

At a meeting of the Belle Isle Bridge Consulting Board Messrs. Adams \& Ellery submitted a proposed "Causeway Plan" as an alternative project to the bridge to Belle Isle. The plan was rejected following careful consideration and investigation.

June 24, 1919.

Resolved by the Common Council that the Corporation Counsel be authorized and directed to prepare the necessary papers for execution by the Commissioner of Public Works of the City of Detroit for and in behalf of the City of Detroit, to be filed with the Secretary of War and Chief of Engineers of the United States Government, asking its consent and approval to the proposed Belle Isle Bridge according to the plans heretofore approved by the Common Council and the Board of Supervisors of Wayne County.

July 15, 1919.

Ordinance authorizing the issuance and sale of $\$ 3,000,000$ of "General Public Improvement Bonds" for the purpose of erecting the Belle Isle Bridge.

July 31, 1919.

Belle Isle Bridge Consulting Board approved of the firm of Esselstyn, Murphy and Hanford for the engineering and supervision of the Belle Isle Bridge.

August 5, 1919.
The Commissioner of Public Works authorized to enter into contract with Esselstyn, Murphy and Hanford Company, for the engineering services in connection with the construction of the Belle Isle Bridge.

Dec. 2, 1919.

The Detroit Common Council authorized the Department of Public Works to enter into contract with the Sullivan Machinery Company, Chicago, Ill., for making test borings for the Belle Isle Bridge.

Dec. 16, 1919.

Plans and specificaitons of the "Subway Section of the Detroit Approach to Belle Isle Bridge" prepared by Esselstyn, Murphy and Hanford approved by Common Council and Commissioner of Public Works authorized and directed to advertise immediately for bids.

Feb. 7, 1920.

Bids received for the construction of the Subway section of the Detroit Approach to Belle Isle Bridge.

Fel). 10, 1920

Common Council authorized the Commissioner of Public Works to enter into contract with the Candler Dock and Dredge Company in the sum of $\$ 360,190.00$ for construction of said subway section.

Feb. 17, 1920.

Contract for above work approved and confirmed by Common Council.

Jan. 18, 1921.

Mr. Daniel B. Luten given 30 days to prepare and present plans to Common Council for a solid masonry bridge.

March 1, 1921.

Esselstyn-Murphy authorized by Common Council to make such modifications of the original reinforced concrete cantilever bridge recommended by the Belle Isle Bridge Commission as will bring the cost within the balance of approximately $\$ 2,500,000.00$.

April 5, 1921.

Revised plans prepared by EsselstynMurphy with specifications for a reinforced concrete cantilever bridge approved by Common Council and Commissioner of Public Works authorized to advertise immediately for proposals for construction.

May 21, 1921.

Bids received by Department of Public Works for construction of Belle Isle Bridge. May 24, 1921.

The Commissioner of Public Works 


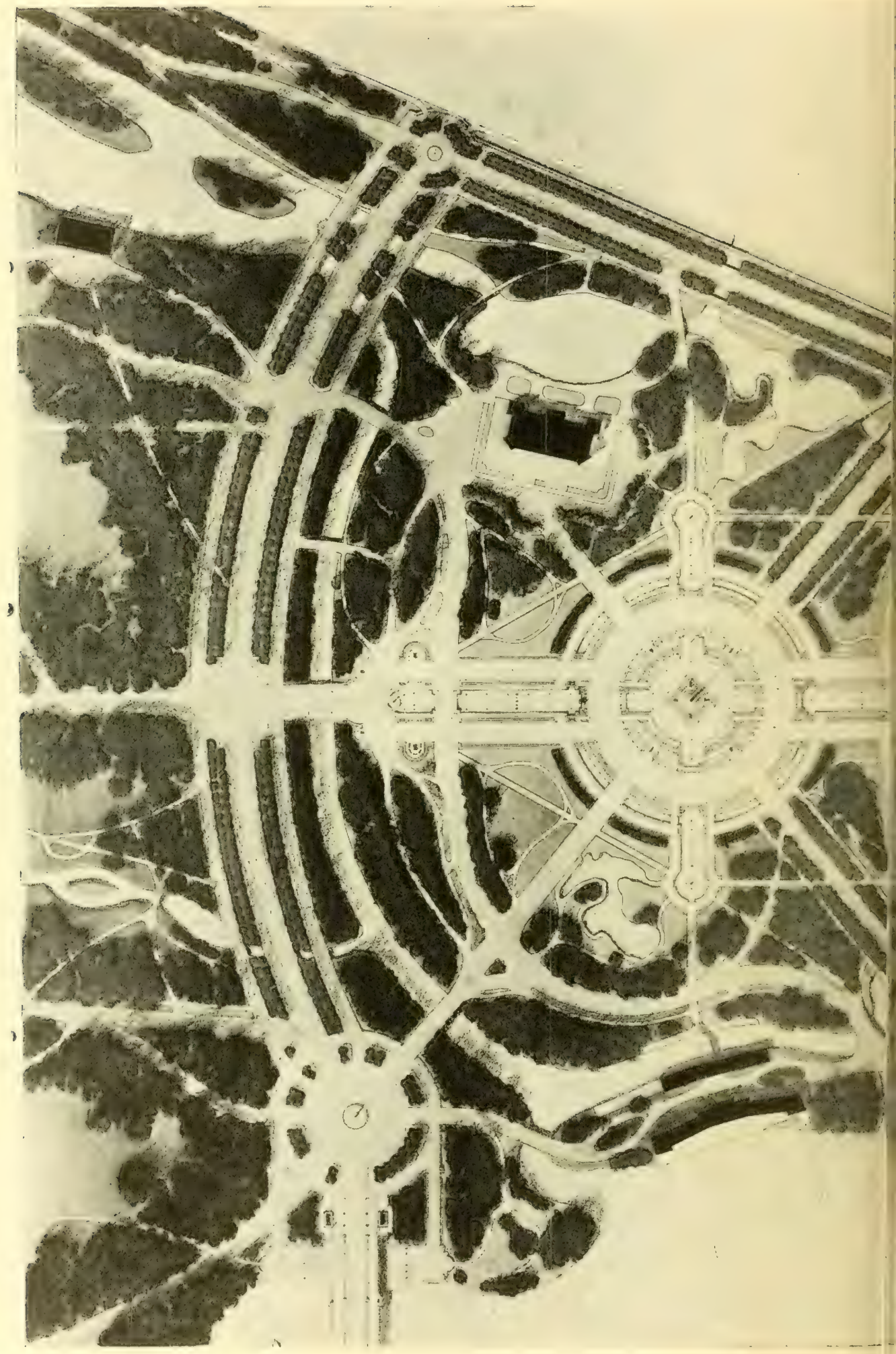




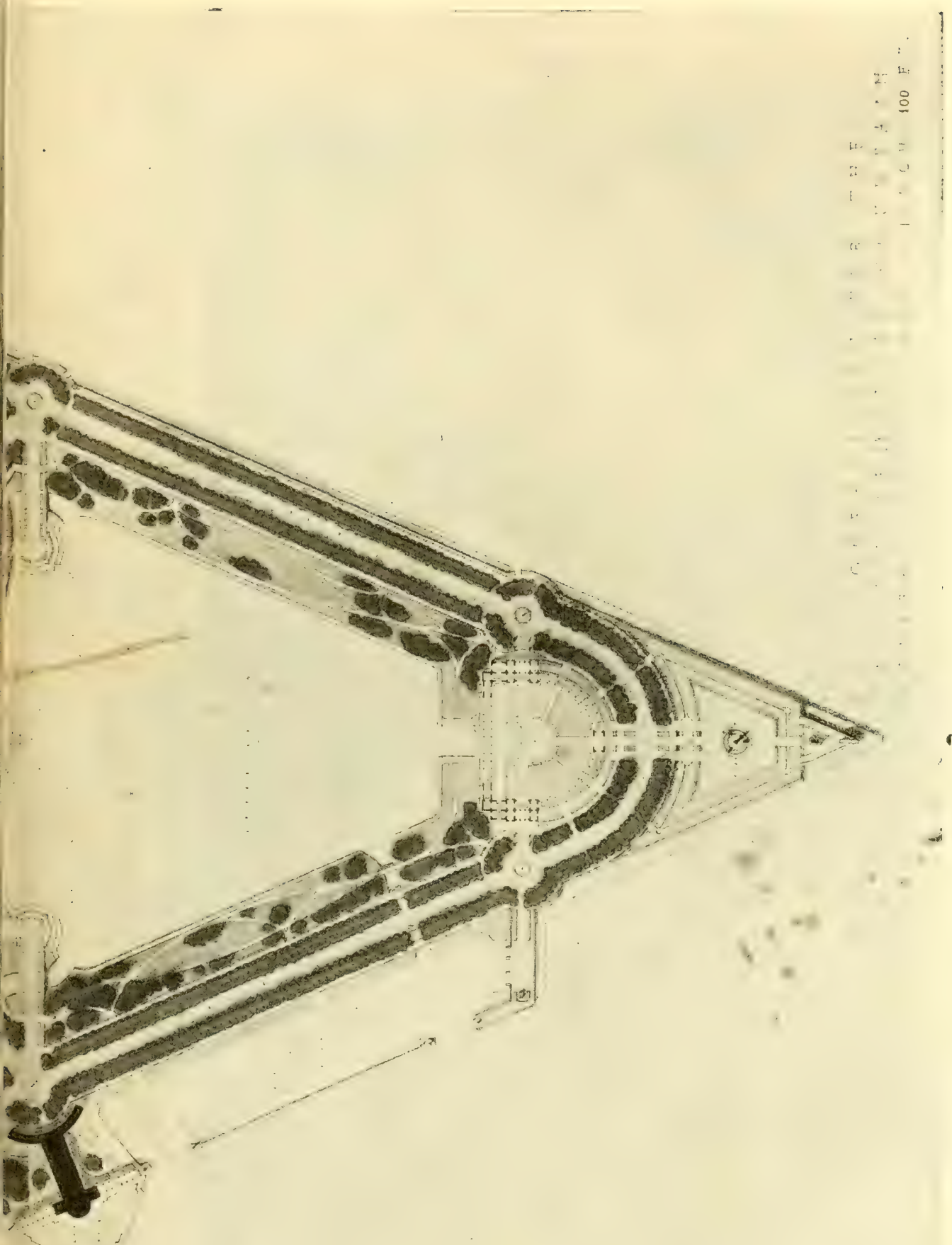




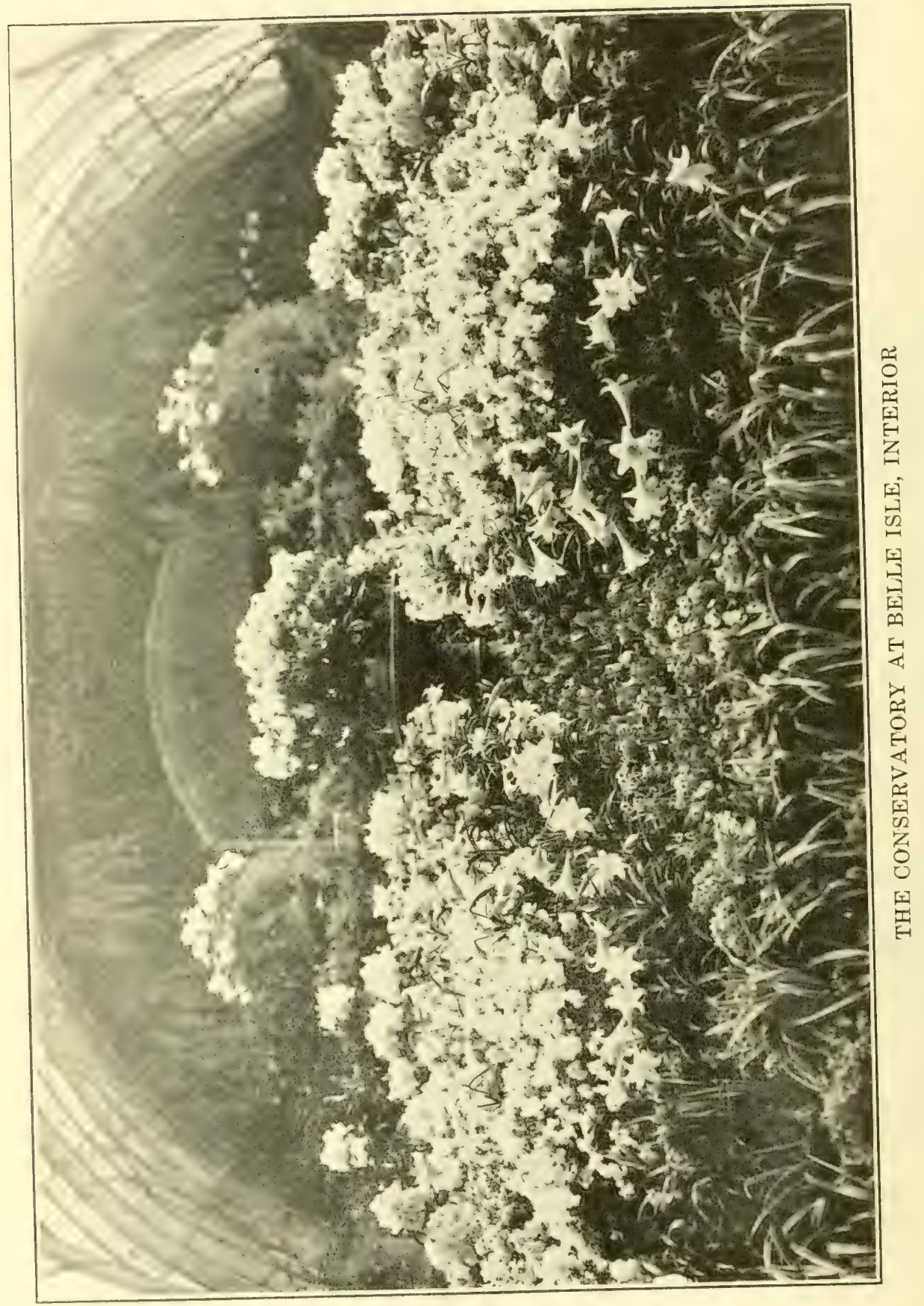


authorized to enter into contract for Belle Isle Bridge Construction with Greiling Bros., Green Bay, Wisconsin in the sum of $\$ 2,011,695.00$ and the Wisconsin Bridge and Iron Works in the sum of $\$ 354,135.00$. The total of these contracts is $\$ 2,365,830.00$. The subway section of the Detroit Ap- proach to Belle Isle Bridge, and a new bus station and toilet building adjacent were completed and opened to the public during the Spring of 1921. Work on the bridge is now under way.

Construction of bridge to be completed in 27 months.

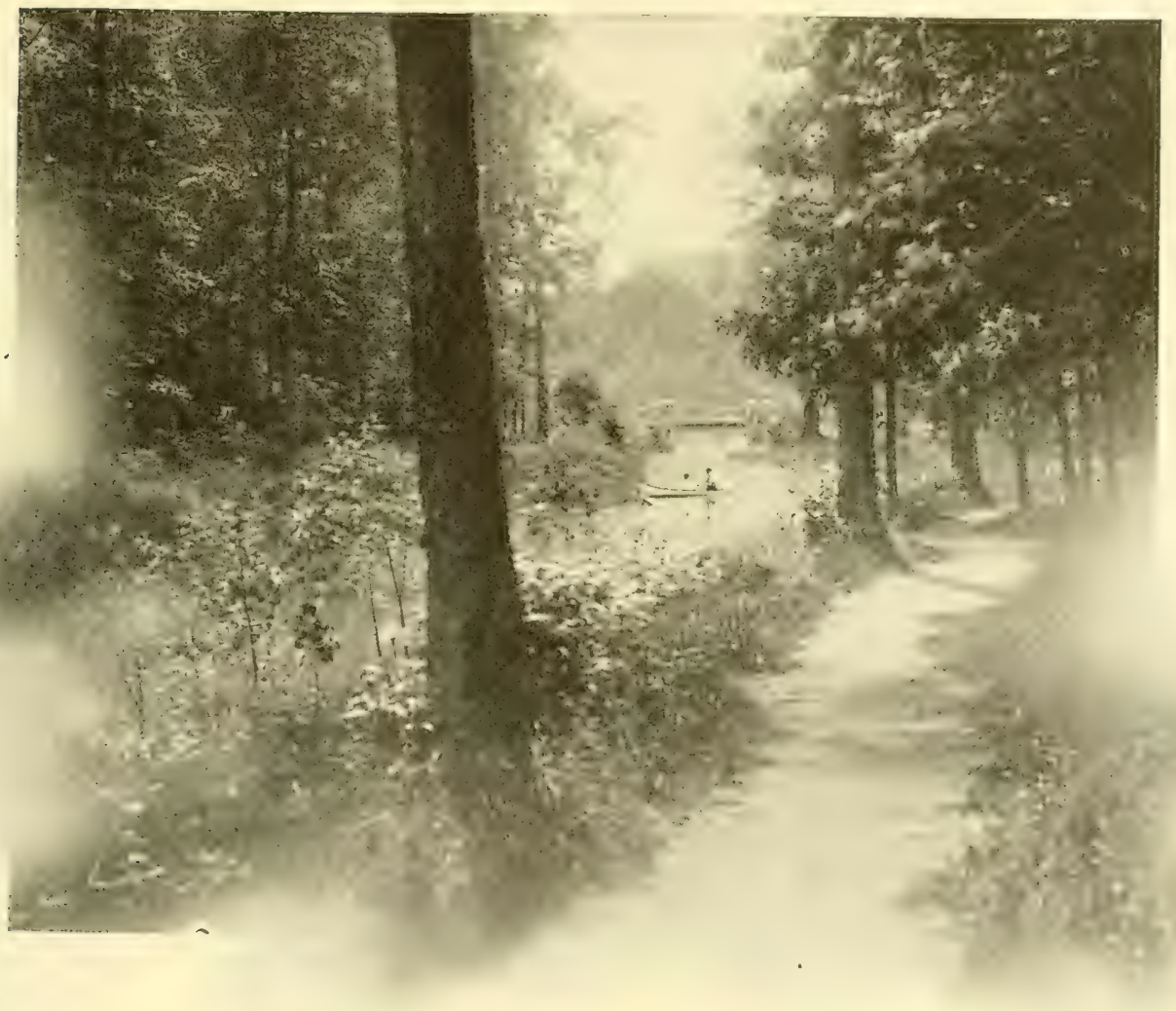

SYLVAN SCENE IN DETROIT PARK 


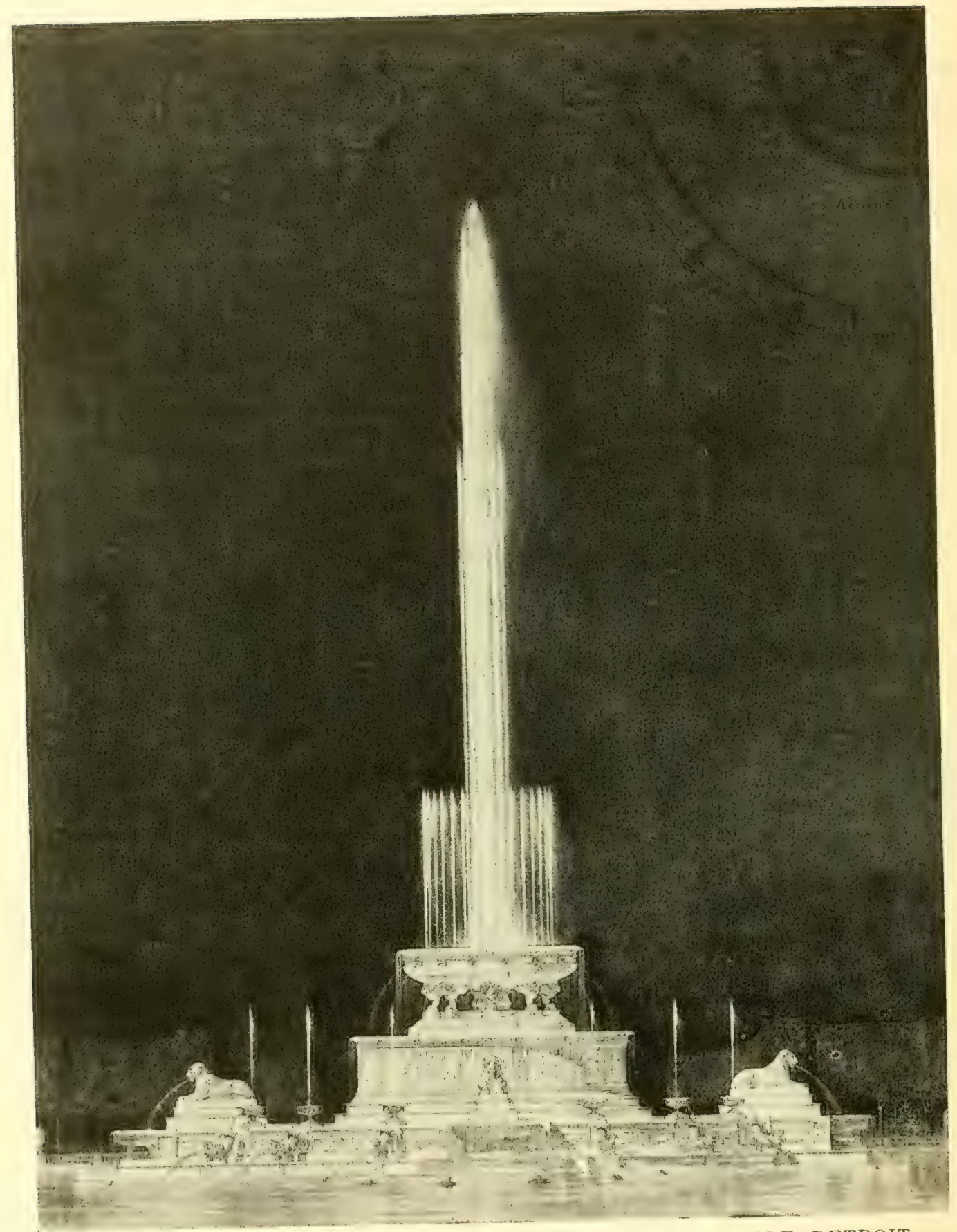

PROPOSED JAMES SCOTT WATER FOUNTAIN FOR BELLE ISLE, DETROIT 


\title{
GIFT OF A GITIZEN
}

\author{
Scott Fountain to be One of \\ Most Beautiful in World.
}

The following brief statements deal with the events leading up to the beginning of the construction work for the erection of the James Scott Fountain on Belle Isle. In the near future there will be published in the Landscape and Art Department of PARKS \& RECREATION a complete description of this great work viewed from the aesthetic standpoint and as a work of art.

\section{March 5, 1910}

James Scott, a citizen of Detroit, died on this date, and under the terms of his will, probated on April 20, 1910, left the bulk of his fortune to the city of Detroit for the erection of a suitable fountain in Belle Isle Park, City of Detroit.

Nov. 29, 1910

By resolution of the Common Council of the City of Detroit the Commissioner of Parks and Boulevards was authorized and directed to accept the bequest of James Scott on behalf of the City of Detroit for the erection of a water fountain on Belle Isle.

\section{March 14, 1912}

City Plan Commission sent communication to the mayor relative to the filling in of the lower end of Belle Isle in preparation for the Scott monument.

\section{March 27, 1912}

City Plan Commission received report that the Common Council allowed the sum of $\$ 100,000.00$ for the filling in of the lower end of Belle Isle. (This appropriation was apparently never used and no further mention of same occurs on the records.)

April 25, 1912

Resolved by the City Plan Commission that the Scott Monument to be erected on Belle Isle be open to competition of artists, sculptors and architects of the entire United States. That the Trustees and Common Council be and are hereby requested to ask the court to set aside Ten Thousand Dollars $(\$ 10,000)$ for prizes to be offered for designs and models to be submitted under the rules to be prepared by the City Plan and Improvement Commission, approved by the
Common Council, to cover such competition. That the selection and approval of design be by said commission, under authority heretofore granted them, by the City of Detroit, and by the Trustees of said fund. Their joint action to be approved by tha Common Council of the City of Detroit.

\section{April 1, 1913}

City Plan Commission sent communication to the executors of the Scott estate asking that the commission be empowered to invite experts to prepare a program for the designing of the Scott Fountain at a cost to the Scott estate for the above mentioned services of experts of $\$ 1,200.00$.

\section{June 7,1913}

Resolved by City Plan Commission to invite Professor Duquesne of Harvard University to visit Detroit to consult with the Commission and Trustees of the Scott estate with regard to the proposed Scott Fountain.

August 14, 1913

City Plan Commission authorized printing of "Program for James Scott Fountain." by Eugene Duquesne.

\section{December 4, 1913}

Above program by Mr. Eugene Duquesne received by City Plan Commission.

\section{February 13, 1914}

The City Plan Commission voted to invite the following firms to compete in the James Scott Fountain competition: McKim, Mead and White, architects, New York, N. Y.; Cass Gilbert, architect, New York, N. Y.; Carrere and Hastings, architects, New

The jury of awards was approved as follows: Charles A. Platt, Walter Cook and Robert S. Peabody, architects; Frederick Law Olmsted, landscape architect, and Daniel C. French, sculptor.

\section{April 22, 1914}

Drawings submitted for the James Scott Fountain were placed on exhibition in the Fisher Arcade to the judges of the competition and the members of the commission and executors of the James Scott estate. May 19, 1914

Report on second stage of James Scott Fountain competition:

The second and final stage of the com- 


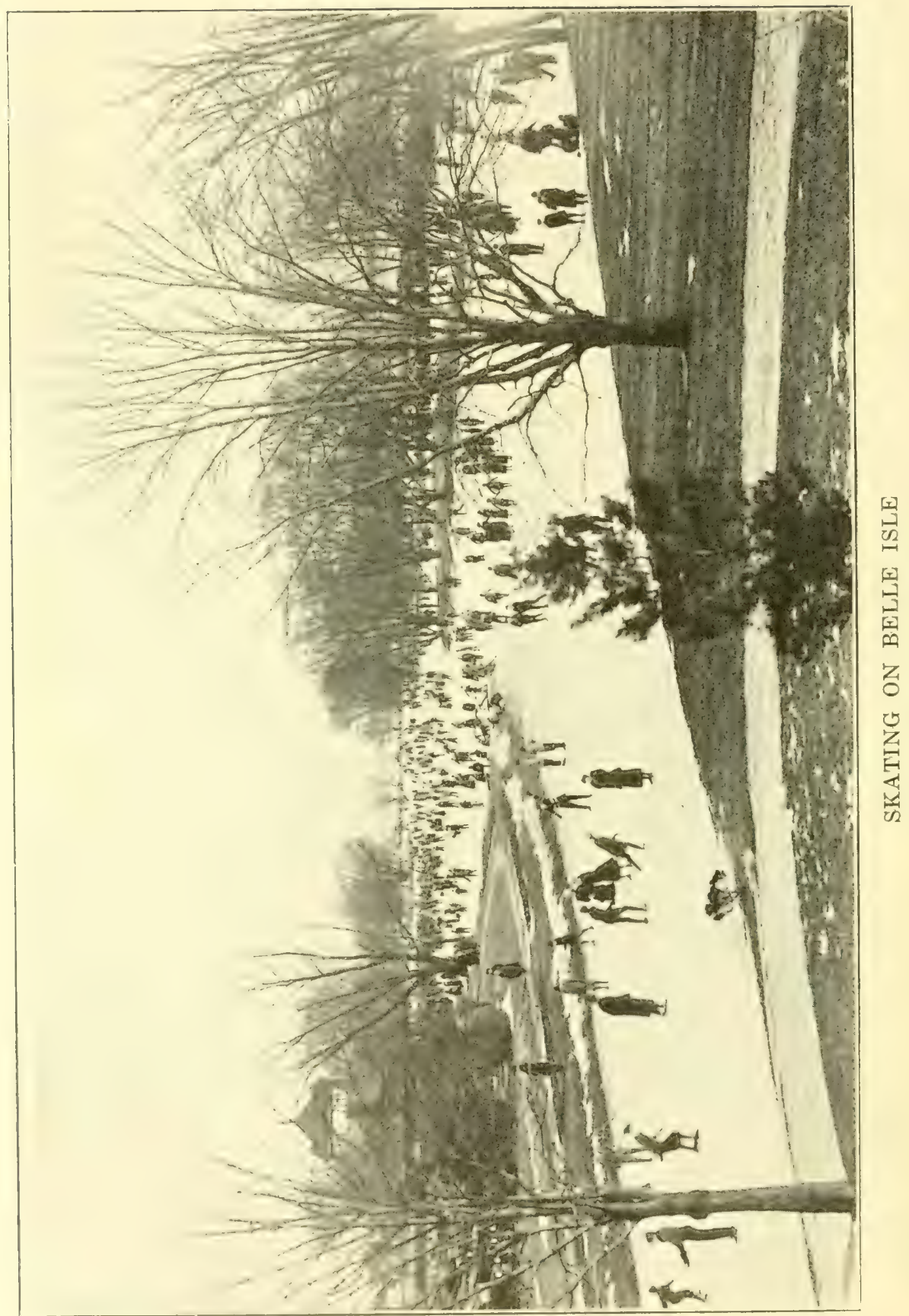




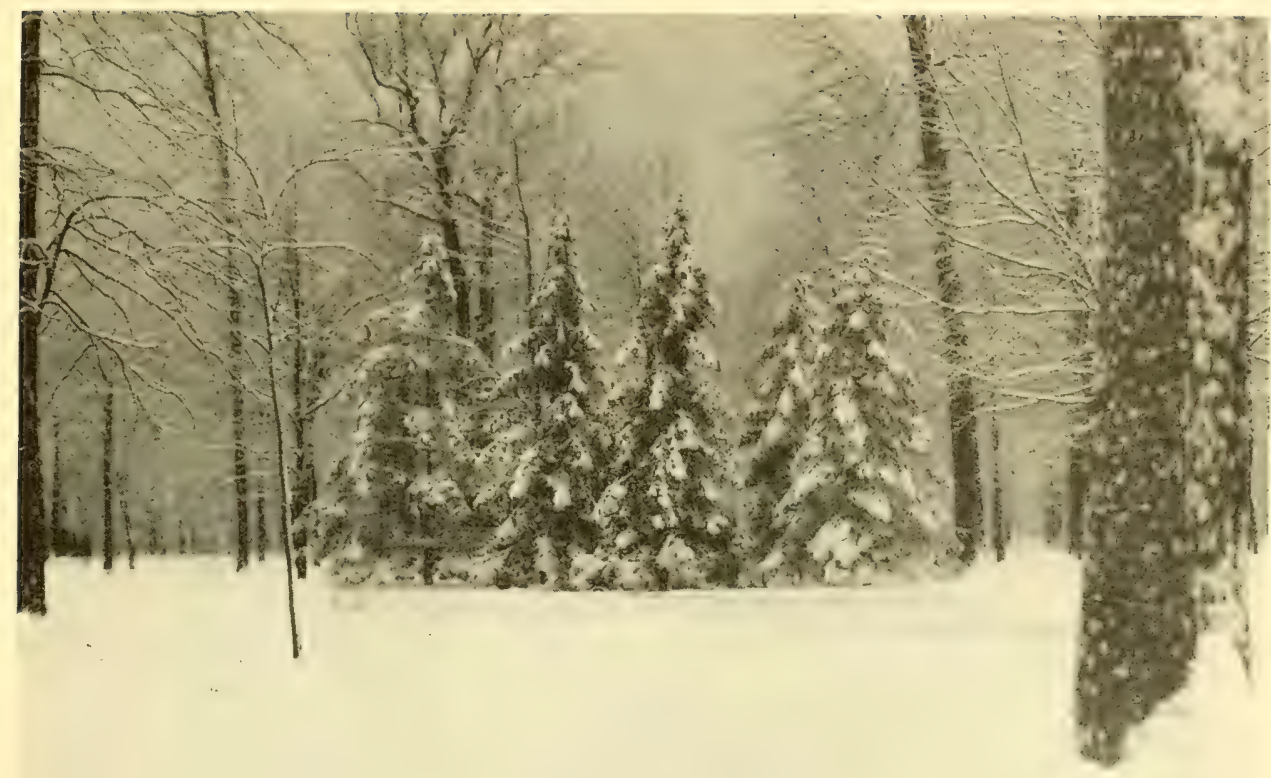

WINTER SCENE AT BELLE ISLE

petition to select an architect to design and superintend the erection of the James Scott Memorial Fountain will be held on June 30 th, under the general direction of Prof. E. J. A. Duquesne, the professional adviser of the City Plan and Improvement Commission. In the first stage of the competition, ninety-two designs were submitted. The New York architects were most numerous, with 38 submissions; next came Boston with 12, followed by Philadelphia with 10 and San Francisco with 6, Detroit, Pittsburg and Washington, D. C., each had 3; St. Louis, Portland, Ore., Seattle, and Chicago, Ill., 2; and Ann Arbor, St. Paul, Cleveland, Cincinnati, Hartford, Los Angeles, Minneapolis, Bridgeport and Brooklyn, 1 each.

The jury was made up of Walter Cook, Charles A. Platt and Robert S. Peabody, architect; Frederick Law Olmsted, landscape architect; and Daniel French, sculptor. The jury spent two days in the examination of the 184 drawings submitted, and from the 92 sets they selected the 7 presented by the following architects: Ames Chard and Doge, Boston, Mass.; Codman and Despradelle, Boston, Mass.; Crane and Ferguson, Boston, Mass.; George W. Jacoby, New
York, N. Y.; Johnson and Mayer, Portland, Ore.; Guy Lowell, Boston, Mass.; Palmer, Hornbostel \& Jones, New York, N. Y.

The seven above named, together with McKim, Mead and White, Carrere and Hastings, and Cass Gilbert, all of New York, will compete in the final stage.

July 10, 1914

The following awards were made on the final competition drawings for the James Sectt Fountain:

Cass Gilbert, New York, N. Y. First prize.

Carrere and Hastings, New York, N. Y. Second prize.

Codman and Despradelle, Boston. Third prize.

Guy Lowell, Boston. Fourth prize.

Jan. 21, 1915

Herbert Adams, sculptor of New York City, recommended by $\mathrm{Mr}$. Cass Gilbert to execute the statue of James Scott.

Sept. 14, 1915

Contract with Mr. Cass Gilbert, architect, for architectural services on James Scott Fountain plans approved by Common Council. 


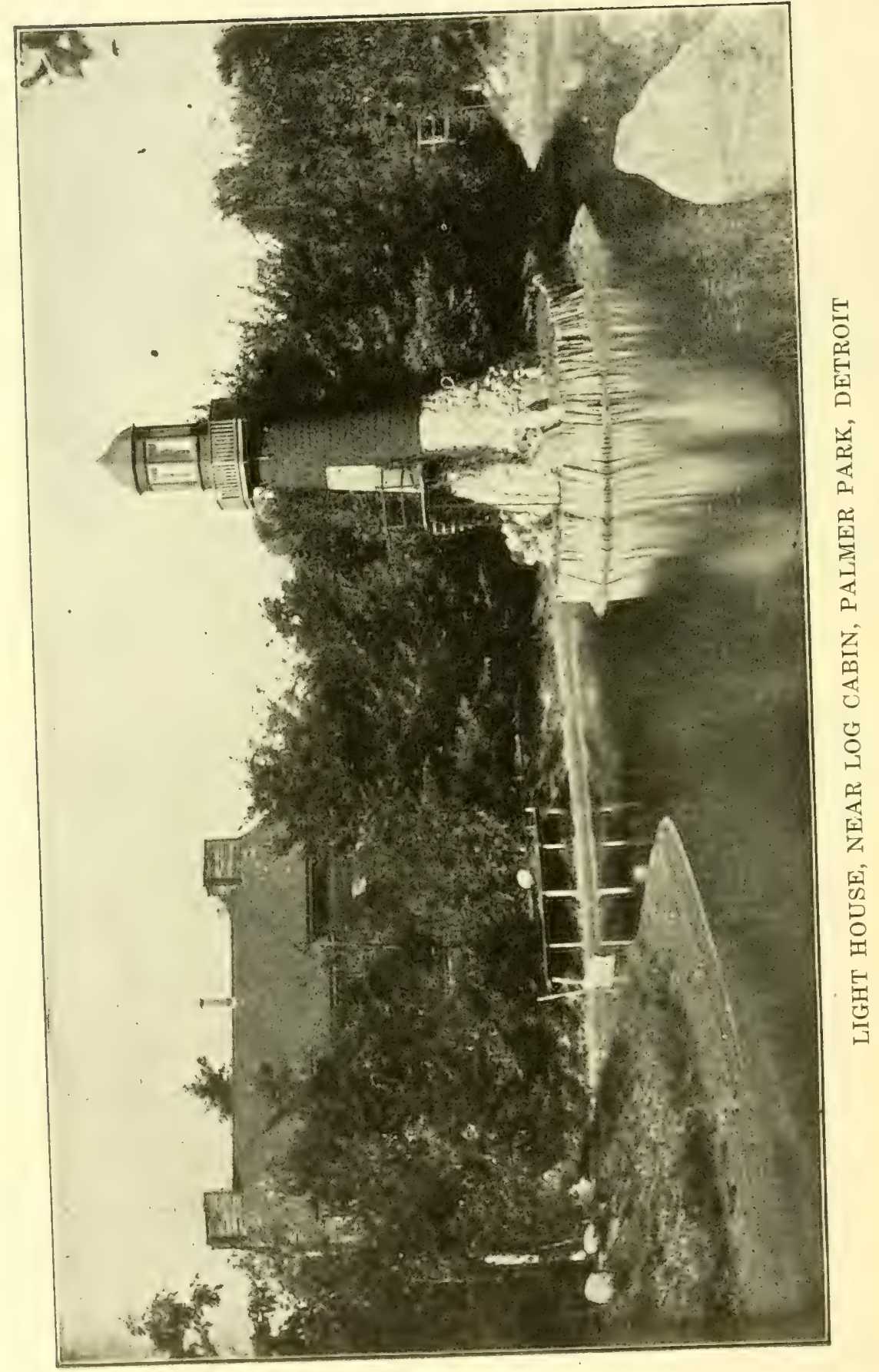




\section{Nov. 9, 1916}

Mr. Cass Gilbert submitted plans and sketches for the James Scott Fountain.

Nov. 27,1917

Bids for piling in connection with Scott Fountain were received, but were rejected later because of excessive cost.

Feb. 18, 1919

Common Council went on record that it would approve an item in the coming fiscal year's estimates in an adequate sum to provide for the construction of a sea wall necessary to retain fill and acquire a desirable site for the Scott Fountain.

\section{July 1, 1919}

The city of Detroit appropriated $\$ 100,000$, which was placed in the Department of Parks and Boulevards' fund to be used for building a retaining wall, and filling in the lower end of Belle Isle in preparation for receiving the James Scott Fountain and the developments surrounding it.

July 22, 1919

Types of dyke or wall to be built by the City of Detroit on the lower end of Belle Isle to receive filling were discussed with Mr. Cass Gilbert.

\section{August 15, 1919}

Plans and specifications received from $\mathrm{Mr}$. Cass Gilbert showing retaining wall and fill-in of lower end of island as revised after conference of July 22, 1919. These were approved, and the Commissioner of Parks and Boulevards authorized to advertise for bids for the dyke and filling for site of proposed James Scott Fountain; bids to be opened September 3, 1919.

Sept. 12, 1919

Contract to build said dyke awarded to Dunbar \& Sullivan in the sum of $\$ 85,200.00$. Sept. 24, 1920

Mr. Cass Gilbert's plans for the general construction and mechanical equipment including specifications, were approved by the James Scott Water Fountain Commission, subject to the cost of the complete structure, after receiving bids. The Commissioner of Parks and Boulevards was authorized to advertise for bids on these approved plans. Nov. 3, 1920

Contract with Mr. Heriert Adams, sculptor, for executing a bronze statue of James Scott to be placed in connection with c.1e James Scott Fountain, was approved by the Common Council in the sum of $\$ 20,000.00$.

\section{March 10, 1921}

Bids for general construction and for echanical and electrical equipment of the James Scott Fountain were received.

May 6,1921

Plans of fountain slightly modified to reduce cost, and four lowest bidders who submitted figures on March 10, 1921, for general construction work, and the two lowest on mechanical and electrical equipment were asked to present revised proposals by June 4, 1921 .

June 4, 1921

The revised bids for the construction and mechanical and electrical equipment of the James Scott Fountain were received.

\section{July 12, 1921}

Communication from the James Scott Water Fountain Commission to the Detroit Common Council recommending that the following contracts be approved:

The John Bollin Company for general construction, in the sum of $\$ 345,200.00$.

The Pittlekow Heating \& Engineering Company for mechanical and electrical equipment, in the sum of $\$ 75,785.00$.

The matter of considering the awarding of the James Scott contracts is to be discussed by the Common Council in Committee on Wednesday, July 20,1921, and will probably be reported out the following Tuesday evening.

The John Bollin Company's proposal specified that the work would be completed in three hundred (300) working days. 


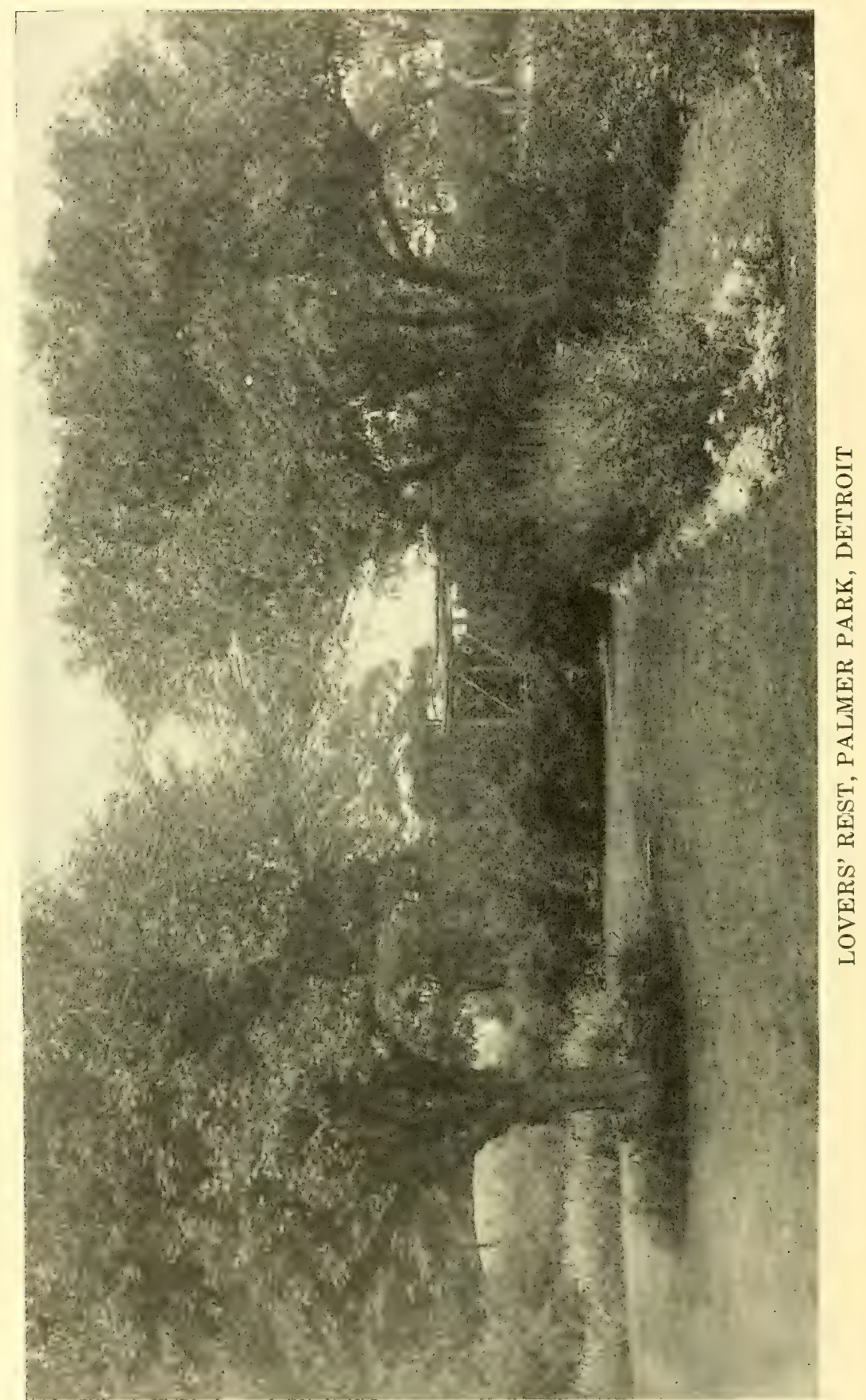




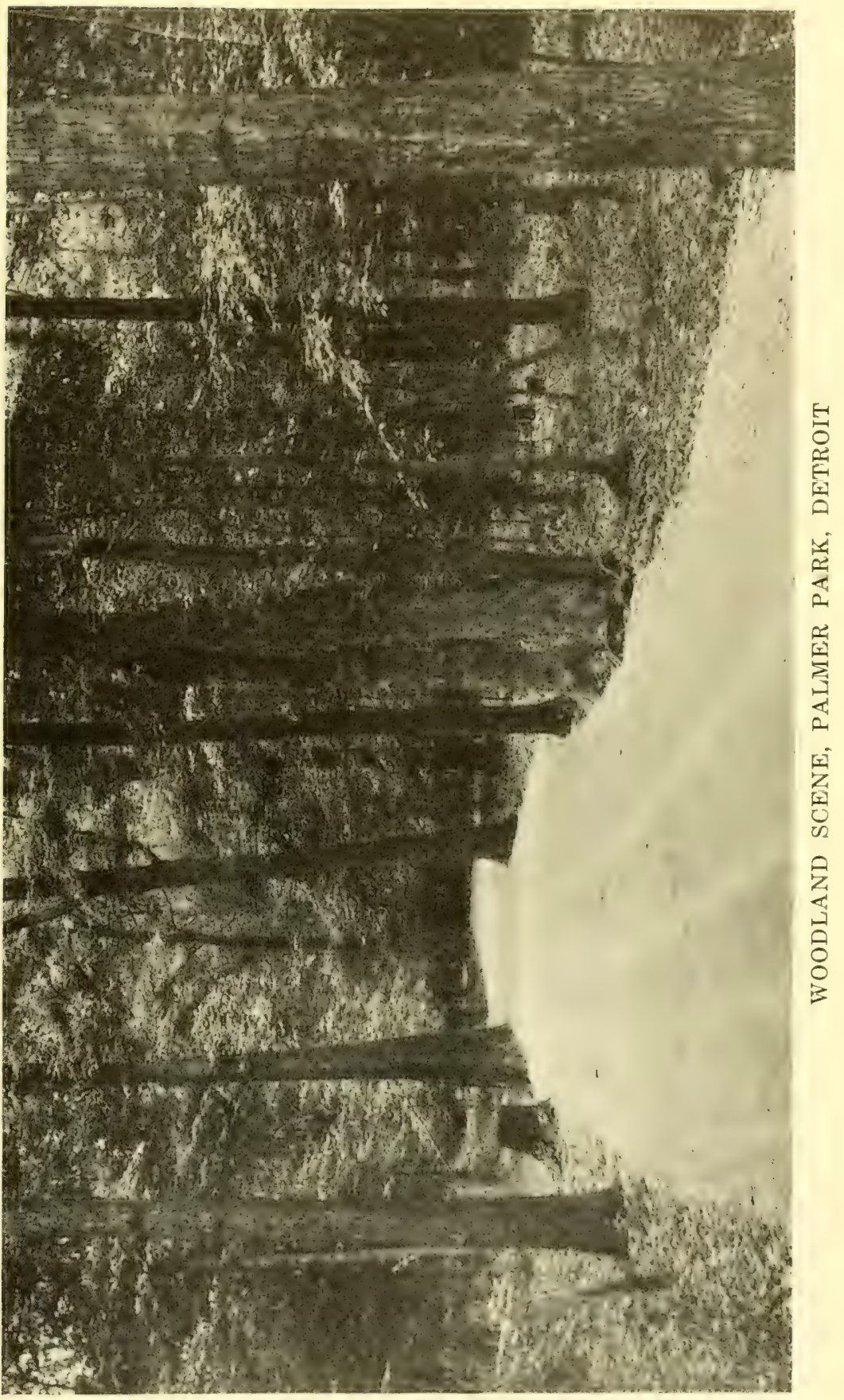




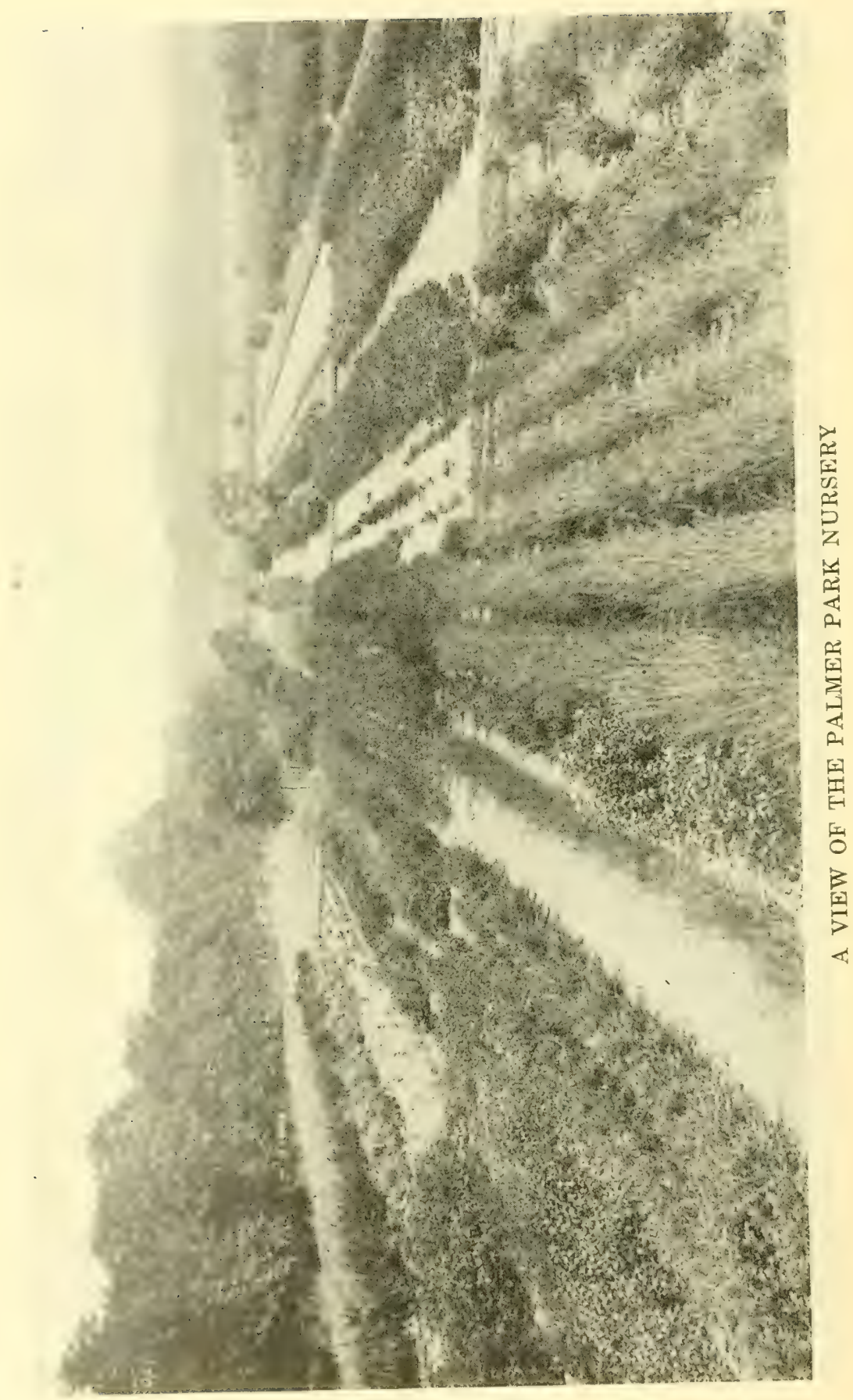




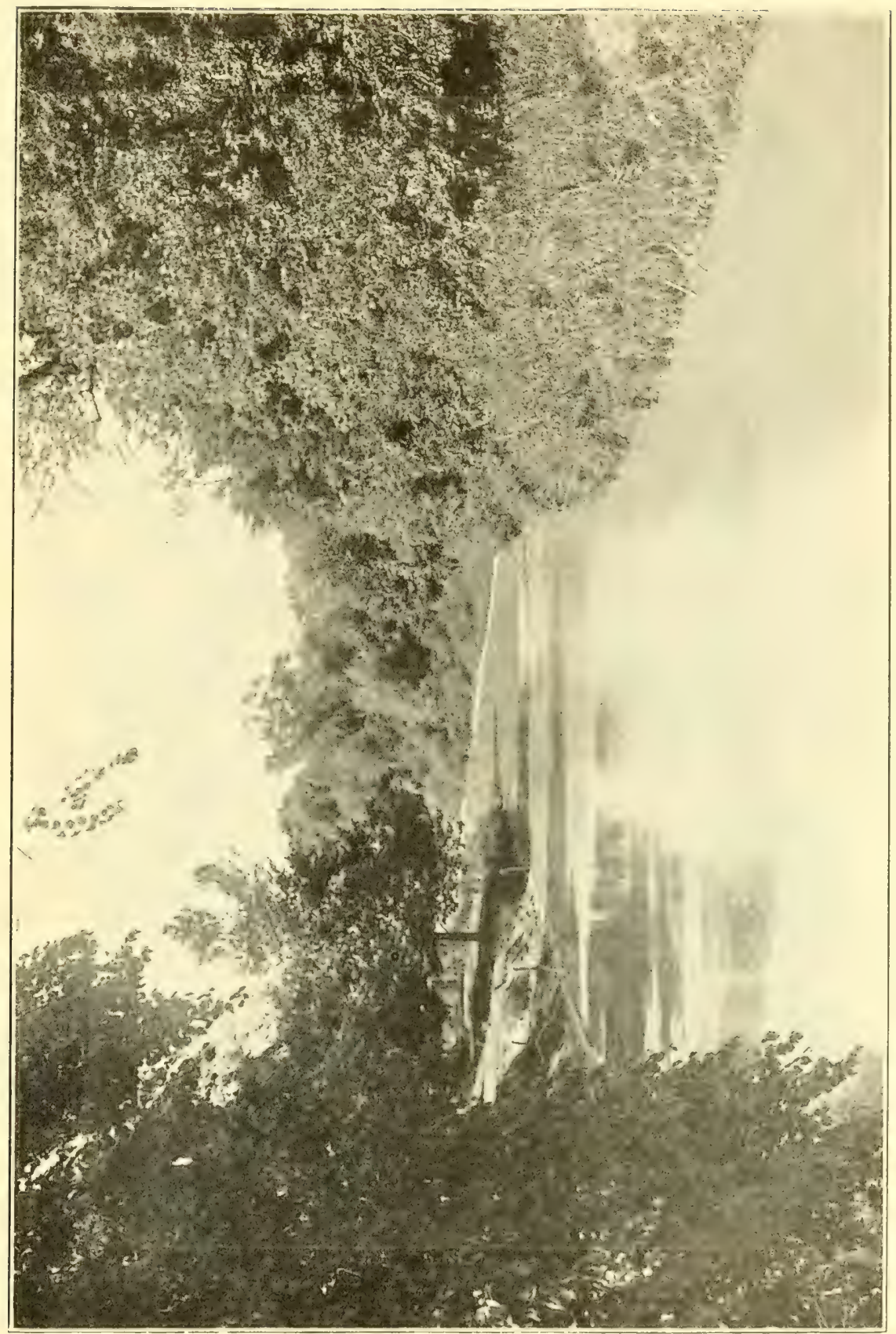

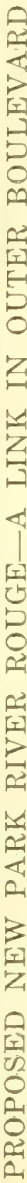




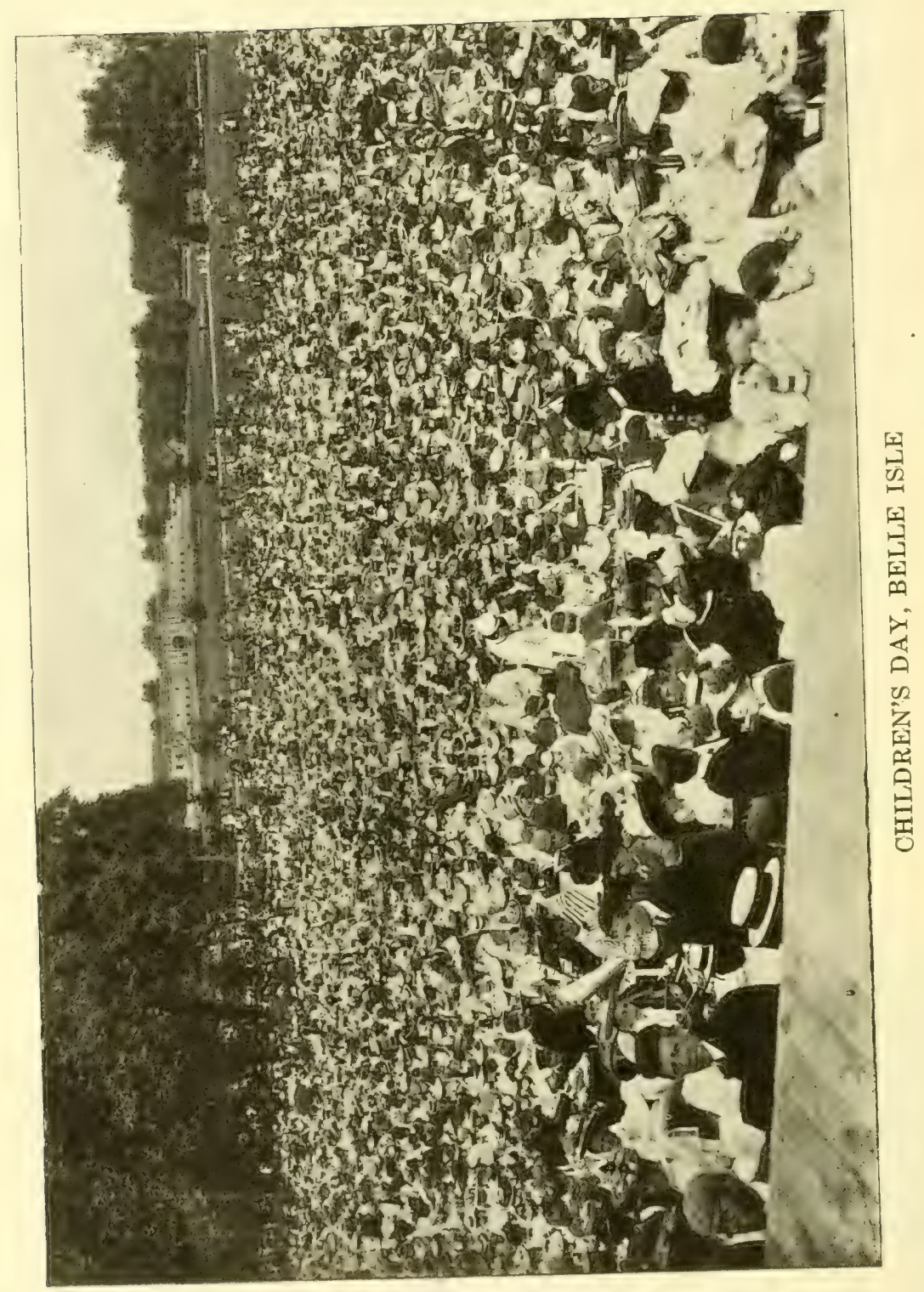




\section{AMERICAN ASSOCIATION OF PARK SUPERINTENDENTS}

\section{OFFICERS 1920-1921}

HENRY W. BUSCH, General Superintendent of Parks, Detroit, Mich.--President J. V. BURGEVIN, Department of Parks, New York City_____-Vice-President EMMETT P. GRIFFIN, Supt. of Parks, East St. Louis, Ill._-_Secretary-Treasurer

\section{BOARD OF DIRECTORS}

L. P. JENSEN, Superintendent "Busch Place"

G. H. HOLLISTER, Superintendent Keney Park St. Louis, Mo. C. A. BOSSEN, Assistant Superintendent of Parks LIONEL EVANS, Superintendent of Parks CHAS. W. DAVIS, Superintendent of Parks Hartford, Conn. WALTER WRIGHT, Secretary Bureau of P. P.\& B. Minneapolis, Minn. Youngstown, Ohio Memphis, Tenn. Chicago, Ill.

\section{0 - 1921 STANDING COMMITTEES}

\section{Horticultural Nomenclature}

Theodore Wirth, Minneapolis, Minn., chairman; H. W. Merkel, New York City; John Dunbar, Rochester, N. Y.

\section{Bird Protection and Propagation}

L. P. Jensen, St. Louis, Mo., chairman; H. W. Merkel, New York City; E. F. A. Reinisch, Topeka, Kan.; Adolph Jaenicke, Fort Wayne, Ind.; H. J. Stoeppler, Louisville, Ky.; Paul B. Riis, Rockford, 111.; E. R. Waldenberger, Niagara Falls, N. Y.; R. L. Powers, Halifax, Nova Scotia.

\section{National, State and Provincial Parks}

F. L. Mulford, Washington, D. C., chairman; Fred Nussbaumer, St. Paul, Minn.; Geo. E. McKinley, Flint, Mich.; J. W. Thompson, Seattle, Wash.; E. T. Mische, Portland, Ore,; J. F. Foster, Chicago, III.; Geo. H. Hollister, Hartford, Conn.; Geo. Champion, Winnipeg, Canada; John G. Morley, San Diego, Calif.; Clarence L. Brock, Houston, Texas; W. P. Long, Boston, Mass.; John Meisenbacher, Tulsa, Okla.; A. N. Robson, New York City.

\section{Playgrounds and Recreation}

C. A. Bossen, Minneapolis, Minn., chairman; A. A. Fisk, Chicago, Ill.; Ernst Strehle, St. Louis, Mo.; M. B. Kannowski, Mitchell, S. D.; R. L. Parker, Hartford, Conn.; Walter Wright, Chicago, 111.; H. G. Evans, Louisville, Ky.; Jas. H. Lowry, Indianapolis, Ind.; Wm. H. Dunn, Kansas City, Kan.; Lionel Evans, Youngstown, Ohio; Geo. A. Hill, Tacoma, Wash.; Harold Neale, New Orleans, La.; Conrad Wolf, Hibbing, Minn.; Grant Forrer, Harrisburg, Pa.; C. P. Connell, Nashville, Tenn.
H. W. Merkel, New York City, chairman; C. W. Davis, Memphis, Tenn.; S. R. De Boer, Denver, Colo.; N. Crist, Atlanta, Ga.; John F. Walsh, New York City; W. R. Reader, Calgary, Canada; John C. Cannon, Chicago, Ill.; F. L. Mulford, Washington, D. C.; H. P. Kelsey, Salem, Mass.; Jas. F. Dawson, Brookline, Mass.; John W. Duncan, Spokane, Wash.; W. R. Pierson, Cromwell, Conn. Donald McLaren, San Francisco, Calif,; Geo. W Hess, Washington, D. C.

City Planning in Relation to Parks and Boulevards

Theo. Wirth, Minneapolis, Minn., chairman: Emanuel T. Mische, Portland, Ore.; Wm. H Dunn. Kansas City, Kans.; John McLaren, San Francisco, Calif.; Alex Stuart, Ottawa, Canada: Geo. W. Burke, Pittsburgh, Pa.; James B. Shea, Boston, Mass; C. H. Meeds, Cincinnati, Ohio; E. A. Miller, New York City; Wm. I. Hoch, Reading, Pa.; Jens Jencen, Chicago, 111.; John Kernan, Lowell, Mass.; G. Hennenhofer, Colorado Springs, Colo.; H. S. Richards, Chicago, Ill.; John Nolen, Cambridge, Mass.

\section{Special Committee on Reorganization}

A. A. Fisk, Chicago, 11l., chairman; Alex Stuart, Ottawa, Canada; Lionel L. Evans, Youngstown. Ohio; J. V. Burgevin, New York City; W. P. Long, Boston, Mass,; Jas. H. Lowry, Indianapolis, Ind.; Will O. Doolittle, Minot, N. D.; Geo. A. Parker, Hartford, Conn.; H. S. Richards, Chicago, Ill.: Theo. Wirth, Minneapolis, Minn.; L. P. Jensen, St, Louis, Mo.; Wm. H. Dunn, Kansas City, Mo.; J. W. Thompson, Seattle, Wash.; H. J. Neale, New Orleans, La.; Emmett P. Griffin, East St. Louis, III. 


\section{PROPOSED GONSTITUTIONAL AMENDMENTS}

\section{PROPOSED CONSTI'TU'TION Preamble}

That we, The American Park Society, may serve the people of America, make more abundant the facilities for a more expressive life for all, to engender a spirit of cooperation between all agencies related to our common cause, to promote the beautiful and orderly building of our cities and towns, to promote the building of parks, gardens and recreation grounds and to interpret their functions and relation to the people, do we institute and ordain this constitution of The American Park Society.

\section{ARTICLE I \\ Name and Object}

Section 1. The name of this Society shall be 'The American Park Society.

Section 2. The object of this Society shall be the gathering of facts and information with reference to parks, gardens and recreation grounds.

The further object of the Society shall be to disseminate this knowledge among its members by all means that shall be determined upon as being most effective and in keeping with the provisions of the Constitution and By-laws.

It shall be the further object of this Society to cooperate with all agencies and people with common objectives and to seek ever the widest diffusion of the knowledge gained in the field of experience and observation, to the end that the motive, purpose and high calling of the membership may make its maximum contribution to society.

\section{ARTICLE II \\ Membership}

Section 1. The Society shall consist of two divisions, the Institute and Forum; Memberships in the Institute shall be designated as Senior, Junior and Honorary Fellows as hereinafter defined. Memberships in the Forum shall be designated as active and sustaining members as hereinafter defined.

Section 2. Membership in the Institute shall be open only to Superintendents of Municipal Parks and Assistant Superin36 tendents, Superintendents of Municipal Recreation Systems and Assistant Superintendents, Park Engineers, Landscape Architects, Engineers and Gardeners, Zoological Directors, Foresters, Botanists, Horticulturists, Agriculturists, Arboriculturists or Specialists in some major sense relating to the above, City and Town Planners, Park and Recreation Commissioners and Secretaries.

Section 3. To become a Senior fellow in the Institute, five years' service and exrerience shall first be required as defined in Article II, Section 2.

Section 4. To become a Junior fellow in the Institute, the requirements shall be the same as for Senior Fellows, defined in Article II, Section 2, except that five years' service and experience shall not be required.

Section 5. Honorary fellowship in the Institute of the Society shall only be conferred by the unanimous vote of the Executive Gommittee and confirmed by the unanimous vote of the convention. It shall be obligatory upon the Executive Committee to transmit their unanimous vote to the convention by a written report explaining and setting forth in detail the service, accomplishment and contribution made by the individual whom they would make an honorary fellow in the Institute of the society. This written report with all signatures of the Executive Committee affixed thereto, shall be transmitted to the Secretary of the Society the first day of the convention. The Secretary shall read this report to the convention on the first day of the convention assembled and attest as to the full and complete signatures of the Executive Committee. The vote of the convention shall be taken during the last business session of the convention assembled.

The honorary fellowship should not be treated lightly. This fellowship should only be conferred upon those who have given unusual service to some branch of the work to which this Society is devoted.

Section 6. The active membership in 
the Forum of the Society shall be open to every one in good standing, twenty-one years old or over.

Section 7. The sustaining membership of the Forum shall be open to Park Commissions, Recreation Commissions, School Boards, Nursery Companies, Manufacturers of Park and Recreation supplies and equipments, or any organization whose business is correlated with the work of this Society.

Section 8. All applications for membership in the Society must be submitted on the application form of the Society to the Executive Committee who will refer the same to the standing committee on membership before submission to the annual convention. The recommendation of the membership committee shall be submitted to the convention, but the recommendation of the membership committee shall not be binding upon, nor shall the same control the action of the convention. The membership committee, may, if they deem it appropriate, submit a statement relative to the character of their recommendation. A vote by ballot may be demanded by any member of the Society in grood standing. Twothirds of members present shall be required to elect candidate to membership.

\section{ARTICLE III. Officers}

Section 1. The officers of this Society shall be a President, Vice-President, Secretary, Treasurer, and a Board of six (6) Directors, who shall be senior fellows of the Institute. These officers shall constitute the Executive Committee of the Society and shall have general management of the affairs of the Society.

Section 2. The term of office of the President, Vice President and SecretaryTreasurer, shall be for one year, beginning at the close of the annual convention at which time such officers were elected and ending at the close of the following annual convention.

Section 3. Members of the Board of Directors shall be elected for a term of three years. Two Directors shall be elected each year.

Section 4. Senior fellows only in the Institute of the Society shall be eligible for election to office in the Society.
Section 5. The officers of the Society shall be the officers of the Forum.

Section 6. There shall be a Forum session as a part of every annual convention. At this session of the Forum all members shall enjoy the right of debate, to introduce resolutions by motion and vote upon the same. All resolutions passed by the Forum must be adopted by majority vote of the Institute before the same are binding upon the Society.

\section{ARTICLE IV. Meetings}

Section 1. Time and Place: An annual convention for the election of officers, hearing of annual reports and such other business as may properly come before it, shall be held each year at such time as may be determined by the Executive Committee. The place of meeting shall be as determined by majority vote at the preceding annual convention.

Should the city selected decline to accept the convention or should circumstances warrant it, the Executive Committee shall have power to make a change of meeting place from that selected by the previous convention.

Section 2. Special Meetings: Special meetings may be called by the President, should occasion require upon written request of twenty-five (25) members or by unanimous vote of the Executive Committee, reasonable notice of such special meeting to be sent to every member.

Section 3. Quorum: A quorum of the Association shall be fifteen (15) members and of the Executive Committee, five (5) members.

\section{ARTICLE V. Branch Societies}

Section 1. The members residing in any state or district, may form a branch or auxiliary Society with the consent of this Society.

Section 2. A petition by half the members in good standing in any state, province or district included in the territory of the proposed branch, must be presented to the Executive Committee at least three days prior to any annual convention and notice of intention to file such petition must be filed with the Secretary at least thirty days before any annual meeting and he must 
notify every member of such proposed petition. The Executive Committee shall consider such petition and the reasons therefor and report its recommendations to the annual convention for final action.

Section 3. A two-thirds vote of the voting members at the annual convention shall be necessary to grant such petition and authorize such branch or auxiliary Society. (See By-law Number 8).

Section 4. The provisions of the Constitution and By-laws of State and Provincial branches must not be in contradiction to the provisions of the Constitution and By-laws of the American Park Society. The name of all State and Provincial branches shall be (substituting the name of State or Province for American Park Society).

\section{AR'TICLE VI. Amendments}

Section 1. Amendments to this Constitution and By-laws may be made at any annual convention by a two-thirds vote of the voting members, provided, that a copy of all proposed amendments shall have been filed with the Secretary at least thirty days previous to the date of the convention and the Secretary shall before such convention, through the official organ or otherwise, notify the entire membership of the proposed amendments.

\section{PROPOSED BY-LAWS}

1. ORDER OF BUSINESS: The following order of business shall be observed at all annual meetings unless set aside by two-thirds vcte of members present and voting:

1. Calling to order and roll call of officers.

2. Reading of minutes of previous meeting.

3. Appointment of Committees.

4. Applications for membership and report of membership committee on same.

5. Election of new members.

6. Reports of Officers and Committees.

7. Communications, Resolutions, Amendments.

8. New Business, Papers, Discussions.

9. Election of Officers. Unfinished business.

Adjournment.

2. ELECTION OF OFFICERS: Offi- cers shall be elected at each annual session as follows: A nominating committee of three Senior Fellows shall be appointed by the President on the opening day of the annual convention, which committee shall later in the session submit a list of names of at least two persons for each office, which list and the names of such other persons as may be placed in nomination by the convention, shall be the nominees and shall be voted upon on the last day of the convention. The vote shall be by ballot and the persons receiving a majority of the vote cast, for each office, shall be declared elected.

3. DUTIES OF OFFICERS: PRESIDENT: The President shall preside at all meetings of the Society or Executive Committee: He shall approve all bills and claims paid by Secretary-Treasurer; be the directing head of the Society during his term of office and perform the usual duties devolving upon a presiding officer of a society of this character.

SECRETARY - TREASURER: He shall keep a record of the proceedings of the Society and conduct its correspondence. He shall submit all bills and claims to the President and upon his approval shall pay the same.

He shall collect all fees and dues or other moneys due the Society and shall have custody of all funds, except as hereinafter defined under caption-Board of Editors, of this by-law. He shall pay all bills approved by himself and the President.

He shall keep an accurate account of the receipts and disbursements of the Society and shall make a full report of same at the annual convention.

$\mathrm{He}$ shall receive a salary and compensation which shall be fixed and determined upon by the Executive Committee.

VICE-PRESIDENT: The Vice-President shall assist the President in directing the affairs of the Society. He will serve as presiding officer in the absence of the President at the annual convention and in the event of the death, resignation or removal of the President, he shall automatically succeed to that office.

BOARD OF DIRECTORS: This board of six members constitutes and is intended as the controlling factor of the Executive Com- 
mittee, representing two-thirds of its membership. Its duties are as set forth for the Executive Committee.

EXECUTIVE COMMITTEE: The Exeeutive Committee shall make all arrangements for meetings of the Society, decide upon features, excursions and inspection tours. It may appoint sub-committees from its members or from the Society. It shall act upon and report with its recommendations to the annual convention, all applications for membership, petitions, or any other matter which may be referred to it, or any new matter which it may see fit to introduce. The Executive Committee shall be the governing body of the Society and shall have full power to act between annual meetings on all matters for the welfare of the Society.

BOARD OF EDITORS: The Society shall publish a monthly magazine, entitled, "Parks \& Recreation" devoted to technical and popular matter pertaining to park and recreation work. The management of this magazine shall be vested in an Editorial Board of three Senior fellows of the Institute of this society as follows:

The Executive Committee shall appoint one managing and two associate editors and shall fix and determine their salaries and compensation. Such appointments shall be for a term of two years. The managing editor shall have general charge of the magazine, and editing the same. He shall be assisted by the associate editors in keeping with policies determined by the Editorial Board. The Editorial Board shall make a detailed financial and business report to the Executive Committee and the same shall be read before the Convention at each annual meeting.

The Secretary of the Society shall submit a certified list of all fellows and members who are entitled to the magazine, to the managing editor and shall attach to this list a check drawn by the Treasurer for an amount equal to three dollars $(\$ 3.00)$, the annual subscription price of the magazine, for each member.

The Editorial Board shall be responsible to the Executive Committee. All resolutions passed by the Convention assembled, in keeping with constitution and by-laws, shall of course, be binding upon the Exe- cutive Committee. All resolutions passed by the Convention assembled and which in any way may relate to the magazine, "Parks \& Recreation", shall be transmitted in writing by the Executive Committee to the Editorial Board with instructions. The Editorial Board shall comply with all such instructions from the Executive Committee.

The financial matters relating to the publication of "Parks \& Recreation", the official organ of the Society, shall be handled by the Board of Editors.

The Executive Committee shall at the first session of each convention, submit any recommendations it may choose to offer and the Society is at each convention to voice its approval or disapproval of current policies or give instructions to the committee concerning any affairs it desires discontinued, altered or instituted as a Society program for the ensuing year.

The Executive Committee shall have power to fill vacancies, not otherwise provided for, should any office become vacant, by death, resignation or removal, but such selection shall only be until the next annual convention.

4. ELECTION OF MEMBERS: Every application for membership must be endorsed by a Senior fellow and presented to the Executive Committee who will refer the same to the standing committee on membership. The report of the membership committee shall be referred to the convention as provided by a provision of the constitution.

5. FEES AND DUES: Applicants for fellowship in the Institute of the Society shall pay a fee with application of Ten Dollars $(\$ 10.00)$, which fee shall be returned to applicant if not elected.

Annual dues for Senior and Junior fellows in the Institute shall be Ten Dollars $(\$ 10.00)$.

Applicants for Active Membership in the Forum of the Society shall pay a fee with application of Five Dollars $(\$ 5.00)$; for Sustaining membership, Ten Dollars $(\$ 10.00)$, which fee shall be returned to applicant if not elected.

Annual dues for Active membership in the Forum of the Society shall be Five Dollars $(\$ 5.00)$. 
The fiscal year of the Society shall be from August 1st to July 31st.

Any member one year in arrears for dues shall without further action be suspended until all arrears are paid.

The annual dues paid by members shall cover their subscription to the official organ of the Society and such bulletins or publications as may be issued.

6. RESIGNATION OR WITHDRAWALS: Any member whose dues are fully paid up may withdraw from the Society by notifying the Secretary and at the discretion of the Executive Committee may be re-instated by payment of dues of current year at time of application for re-instatement.

Suspended members cannot be re-instated or again become members except by paying all arrears.

7. MEMBERSHIP COMMITTEE: On the first day of Convention, after the reading of minutes of previous meeting, the President shall appoint an Institute and Forum Membership Committee of three each. Each Committee shall report on their respective applicants, and the same referred to their respective convention bodies.
8. BRANCH SOCIETIES: Only members in good standing in this Society shall be eligible for membership in any branch of this Society and dues paid to any branch shall not be in lieu of dues to this Society, but shall be in addition thereto.

No meeting of a branch of this Society shall be held to conflict with the regular annual convention of the parent Society.

9. EXPULSION: Any member of this Society may be suspended or expelled for unprofessional conduct or conduct unbecoming a member of this Society, PROVIDED, charges in writing against such member have been filed with the Stcretary at least 30 days prior to the annual convention. The accused shall be notified of such charges and afforded an opportunity to appear and present a defense at the time of the hearing of the charges.

This by-law shall also apply to members who may violate any of the provisions of the Constitution or By-Laws.

10. This Constitution and By-laws shall become effective immediately upon its adoption by the Convention.

Adopted,

Date.

\section{Present Qualifications for Membership}

SENIOR MEMBERS-Persons of at least five years' practical experience in public or private parks as Superintendent, Assistant Superintendent, Landscape Architect or Engineer, Forester or other Park Executive, or a specialist in Arboriculture, Horticulture or Forestry.

JUNIOR MEMBERS-Same as Senior, except having less than five years' experience.

ASSOCIATE MEMBERS-Park Commissioners, Secretaries, or other officials directly connected with park or recreational work or persons interested in or connected with Horticulture, Forestry, Landscape Engineering or Architecture, or retired Park Executives.

SUSTAINING MEMBERS-Park Boards, Commissions or other governing bodies, or public-spirited individuals who contribute $\$ 10.00$ per year to the Association, and who shall be entitled to the publications of the Association, also to attend conventions.

All applications subject to approval by Executive Committee and election at Annual Convention.

Admission fee, $\$ 10.00$, which includes first year's dues. Dues, $\$ 5.00$ per year. 


\section{ATTENTI0N!}

\section{Park Departments}

Five Elk and 22 Deer

ForSale. PricedRight.

These are a fine

lot of animals.

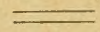

Address

O. D. ARP, Supt.

Council Bluffs Park Board COUNCIL BLUFFS, IOWA 

Makers

Syracuse, N. Y. PAT. JAM. 21, 1908 
LIBRARY OF CONGRESS

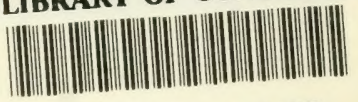

\section{$0000911697 ?$}

